OPEN ACCESS

Edited by:

Solange I. Mussatto,

Technical University of Denmark,

Denmark

Reviewed by:

Sujit Jagtap,

University of Illinois

at Urbana-Champaign, United States

Yejun Han,

Institute of Process Engineering

(CAS), China

${ }^{*}$ Correspondence:

Seiichi Taguch

st206172@nodai.ac.jp

Specialty section:

This article was submitted to Industrial Biotechnology,

a section of the journal

Frontiers in Bioengineering and

Biotechnology

Received: 16 October 2020 Accepted: 17 December 2020

Published: 04 February 2021

Citation:

Nduko JM and Taguchi S (2021)

Microbial Production

of Biodegradable Lactate-Based

Polymers and Oligomeric Building

Blocks From Renewable and Waste

Resources.

Front. Bioeng. Biotechnol. 8:618077.

doi: 10.3389/fbioe.2020.618077

\section{Microbial Production of Biodegradable Lactate-Based Polymers and Oligomeric Building Blocks From Renewable and Waste Resources}

\author{
John Masani Nduko' and Seiichi Taguchi ${ }^{2 *}$ \\ ${ }^{1}$ Department of Dairy and Food Science and Technology, Faculty of Agriculture, Egerton University, Egerton, Kenya, \\ ${ }^{2}$ Department of Chemistry for Life Sciences and Agriculture, Faculty of Life Sciences and Agriculture, Tokyo University \\ of Agriculture, Tokyo, Japan
}

Polyhydroxyalkanoates (PHAs) are naturally occurring biopolymers produced by microorganisms. PHAs have become attractive research biomaterials in the past few decades owing to their extensive potential industrial applications, especially as sustainable alternatives to the fossil fuel feedstock-derived products such as plastics. Among the biopolymers are the bioplastics and oligomers produced from the fermentation of renewable plant biomass. Bioplastics are intracellularly accumulated by microorganisms as carbon and energy reserves. The bioplastics, however, can also be produced through a biochemistry process that combines fermentative secretory production of monomers and/or oligomers and chemical synthesis to generate a repertoire of biopolymers. PHAs are particularly biodegradable and biocompatible, making them a part of today's commercial polymer industry. Their physicochemical properties that are similar to those of petrochemical-based plastics render them potential renewable plastic replacements. The design of efficient tractable processes using renewable biomass holds key to enhance their usage and adoption. In 2008, a lactate-polymerizing enzyme was developed to create new category of polyester, lactic acid (LA)-based polymer and related polymers. This review aims to introduce different strategies including metabolic and enzyme engineering to produce LA-based biopolymers and related oligomers that can act as precursors for catalytic synthesis of polylactic acid. As the cost of PHA production is prohibitive, the review emphasizes attempts to use the inexpensive plant biomass as substrates for LA-based polymer and oligomer production. Future prospects and challenges in LA-based polymer and oligomer production are also highlighted.

Keywords: bioplastics, LA-based polymers, LA-based oligomer, lignocellulosic biomass, microbial secretion, PLA 


\section{INTRODUCTION}

Conventional plastics derived from fossil fuels have become indispensable in modern human life owing to their superior chemical and physical properties that give them versatile qualities such as lightness, robustness, durability, and resistance to degradation (Możejko-Ciesielska and Kiewisz, 2016; Narancic and O'Connor, 2019). Plastics have effectively replaced a number of materials/substances and have found broad applications in industrial, domestic, and medical fields as disposable gears, packaging, furniture, machinery frames, and other accessories (Anjum et al., 2016; Narancic and O'Connor, 2019). Global plastic production reached 359 million tons in 2018 with projected increase in production (Plastics Europe, 2019). The production of plastics has raised environmental concerns because plastics are non-biodegradable and persistent, and they accumulate in the environment, posing threat to life on earth (Alcântara et al., 2020). Although plastics can be recycled, only a small percentage of the plastics (6\% of total plastic demand) are recycled because recycling is a time-consuming process, and it also alters the properties of plastic materials, resulting in lowquality plastics (Narancic and O'Connor, 2019). Most of the plastics are disposed in landfills where their degradation is low or used for energy recovery. Disposal of plastics by incineration generates toxic by-products such as furans, polychlorinated biphenyls, dioxins, and mercury and is expensive (Verma et al., 2016; Raza et al., 2018).

As a result of the challenges and concerns with petroleumderived plastics along with the paradigm shift toward development of bioeconomies, researchers have been compelled to explore new approaches of synthesizing biologically produced plastics (bioplastics) that are biodegradable, eco-friendly, and produced from plant biomass/renewable resources as plastic alternatives (Nduko et al., 2015; Możejko-Ciesielska and Kiewisz, 2016; Alcântara et al., 2020). Such bioplastics include the polyesters, polyhydroxyalkanoates (PHAs) and polylactic acid (PLA), which possess similar physicochemical, mechanical, and thermal properties as conventional plastics (Taguchi, 2010; Nduko et al., 2012a; Kourmentza et al., 2017). PHAs belong to a class of natural biodegradable and biocompatible polyesters that are accumulated under unbalanced growth conditions as intracellular carbon and energy reserves by various microorganisms (Możejko-Ciesielska and Kiewisz, 2016; Tarrahi et al., 2020). Currently, more than 150 different 3-, 4-, 5-, and 6-hydroxy fatty acid monomer constituents (Figure 1) containing straight, branched, saturated, unsaturated, and aromatic structures ( $R$-side chain) in PHA have been documented in more than 90 genera of microbial species (Anjum et al., 2016; Meng and Chen, 2018; Raza et al., 2018). Based on carbon chain length of the monomeric unit $(R)$, PHAs have been classified into three classes (Carpine et al., 2020);

i Short-chain-length PHAs (scl-PHAs). The monomeric units consist three to five carbon atoms such as polyhydroxybutyrate $[\mathrm{P}(3 \mathrm{HB})]$, poly(4-hydroxybutyrate) $\mathrm{P}(4 \mathrm{HB})$, and poly(3-hydroxyvalerate) $\mathrm{P}(3 \mathrm{HV}$; Anjum et al., 2016). These polymers are produced by organisms such

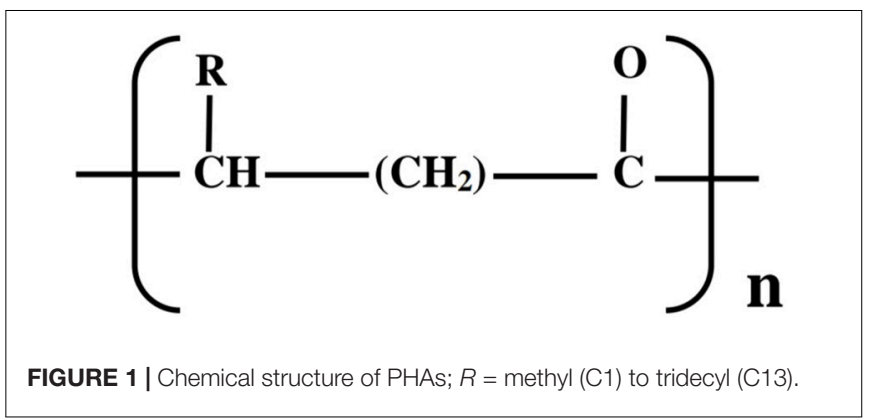

as Cupriavidus necator and Alcaligenes latus (Lee and $\mathrm{Na}, 2013$; Raza et al., 2018). These scl-PHAs exhibit thermoplastic material properties similar to polypropylene (PP; Wang et al., 2016).

ii Medium-chain-length PHAs (mcl-PHAs). Their monomeric units consist 6 to 14 carbon atoms. They are produced by several bacteria such as Pseudomonas putida and Pseudomonas mendocina. The mcl-PHAs are flexible and elastic similar to rubber. They also possess low crystallinity and tensile strength and have high melting point and glass-transition temperatures (Nduko et al., 2012a; Gopi et al., 2018).

iii Long-chain-length PHAs. Their monomeric units have carbon atoms more than 14 . These have been documented in the bacteria Shewanella oneidensis and Aureispira marina (Suriyamongkol et al., 2007).

Among the PHAs, $\mathrm{P}(3 \mathrm{HB})$ was the first to be identified in 1926 in the bacterium Bacillus megaterium (Lemoigne, 1926). $\mathrm{P}(3 \mathrm{HB})$ has been widely studied and characterized, and cells accumulate $\mathrm{P}(3 \mathrm{HB})$ up to $92 \%$ of the cell dry weight (Norhafini et al., 2019). This polymer has similar thermal properties to that of PP., However, $\mathrm{P}(3 \mathrm{HB})$ has difficulties in processability because of its brittle nature, limiting its applications (Kourmentza et al., 2017). As a result, $\mathrm{P}(3 \mathrm{HB})$ has been copolymerized with a number of monomers such as 3-hydroxyvalerate $(3 \mathrm{HV})$ to form a copolymer, $\mathrm{P}(3 \mathrm{HB}-\mathrm{co}-3 \mathrm{HV})$, which has improved material properties (tougher and flexible and acquires broader thermal processing properties) compared with $\mathrm{P}(3 \mathrm{HB})$ homopolymer (Grigore et al., 2019). Copolymerization of 3HB with 3hydroxyhexanoate $(3 \mathrm{HHx})$ generated a copolymer, $\mathrm{P}(3 \mathrm{HB}-\mathrm{co}-$ $3 \mathrm{HHx}$ ), which is produced at industrial scale by Kaneka Co. Ltd (López et al., 2015; Nduko and Taguchi, 2019).

Polylactic acid is one of the most promising biodegradable and biocompatible aliphatic thermoplastic with extensive mechanical property profile (Li et al., 2020). PLA is obtained from lactic acid (LA), a naturally occurring organic acid produced by microbial fermentation from renewable resources such as sugars obtained from corn, cane sugar, and sugar beets (Van Wouwe et al., 2016). On hydrolysis, PLA produces LA; hence, PLA can be produced and used as an environment-friendly material (Singhvi et al., 2019). PLA is highly versatile, highstrength, and high-modulus polymer that yields materials with potential use in industrial packaging or as biocompatible medical devices (Matsumoto and Taguchi, 2010). PLA has good 
processability, and its manufacturing is amenable and can adapt the conventional plastic equipment for production of molded parts, films, and fibers (Castro-Aguirre et al., 2016). LA is a chiral molecule existing in both $\mathrm{L}$ and $\mathrm{D}$ isomers. These monomers can be polymerized into pure poly-L-LA (PLLA), pure poly-D-LA (PDLA), or poly-D-LLA, giving high-molecularweight crystalline, or amorphous polymers (Auras et al., 2004; Tyler et al., 2016).

Polylactic acid is normally synthesized in three steps: (i) LA production by microbial fermentation, (ii) LA purification followed by cyclic dimer formation (lactide), and (iii) polycondensation of LA or ring-opening polymerization (ROP) of the cyclic lactides (Auras et al., 2004; Castro-Aguirre et al., 2016). Polycondensation is the least expensive route for PLA synthesis; however, it does not give a solvent-free high-molecular-weight PLA (Auras et al., 2004). Consequently, ROP has emerged as the most common route to synthesize high-molecular-weight PLA (Pretula et al., 2016). ROP consists of three processes: polycondensation, depolymerization, and the ring opening of the LA cyclic dimer in the presence of a catalyst (Auras et al., 2004). The process also involves complicated and expensive purification steps, rendering the ultimate products more expensive compared to their petroleum-based counterparts (Taguchi, 2010). The catalysts used are mostly transition heavy metals, particularly tin, aluminum, lead, zinc, bismuth, ion, and yttrium (Mehta et al., 2005). However, trace residues of the heavy metal catalysts are unwanted in materials for specific applications such us in medical and food contact surfaces (Taguchi, 2010; Nduko et al., 2012a; Matsumoto and Taguchi, 2013a). Therefore, the replacement of heavy metal catalysts with safe and environmentally acceptable alternatives has been important concern.

Enzymatic polymerization of LA monomers has emerged as one of the most viable and environmentally benign alternative methods for PLA production (Riaz et al., 2018). In the year 2008, Taguchi et al. (2008) established for the first time a whole-cell biosynthetic system. In that system, LA was polymerized alongside $3 \mathrm{HB}$ to produce $\mathrm{P}(\mathrm{LA}-\mathrm{co}$ $3 \mathrm{HB}$ ) copolymer without the need for heavy metal catalysts, extremely pure monomers, anhydrous conditions, and high temperatures. From these pioneering studies, efforts have been made toward the synthesis of $\mathrm{P}(\mathrm{LA}-\mathrm{co}-3 \mathrm{HB})$, PLA homopolymer, and polymerizing other monomers such as glycolate and $2 \mathrm{HB}$ using microbes (Matsumoto et al., 2011a, 2013; Yang et al., 2013; Nduko and Taguchi, 2019). In addition, a system for the production of LA oligomers by microorganisms has been established (Utsunomia et al., 2017c). These oligomers are polymerized into $\mathrm{P}(\mathrm{LA}-\mathrm{co}-3 \mathrm{HB})$, thereby shortening the process for PLA synthesis.

Polyhydroxyalkanoates and PLA have found many applications in domestic, agricultural, and industrial sectors but mostly in the medical field (Albuquerque and Malafaia, 2018). The polymers have been produced and improved for diverse biomedical applications such as making absorbable sutures, nerve guides, bone marrow scaffolds, repair patches, cardiovascular patches, heart valves, nerve repair devices, tendon repair devices, orthopedic pins, tissue engineered cardiovascular devices, articular cartilage repair devices, guided tissue repair/regeneration devices, and wound dressings (Masood et al., 2015; Elmowafy et al., 2019). The PHAs and PLA have also been used as nanoparticles for drug delivery, biocompatible porous implants and implant coatings, scaffolds, and tissue engineering applications such as antibacterial agents (Gadgil et al., 2017). PHAs also have potential use in the formation of necessities such as packaging materials, consumer and household goods, furniture, sports, health and safety automotive and transport sector, and the construction and building sector (Vijayendra and Shamala, 2014; Elmowafy et al., 2019). This indicates that PHAs and PLA have high potential, and their optimum production is of interest.

In this review, we highlight novel ideas that introduce concepts of the microbial production of $\mathrm{P}(\mathrm{LA}-\mathrm{co}-3 \mathrm{HB}), \mathrm{PLA}$, and LA oligomers using engineered microbes. We discuss the creation of the microbial cell factory for $\mathrm{P}(\mathrm{LA}-\mathrm{co}-3 \mathrm{HB})$ synthesis and give a synopsis of LA monomer improvement in the copolymer and eventual PLA biosynthesis, properties and degradation of the LAbased polymers [more information was discussed in Nduko et al. (2015)], the use of integrated lignocellulosic biomass refineries for polymer and oligomer production, and the recent reports on the enabling technologies such as metabolic engineering, protein engineering and genetic engineering, and fermentation media manipulation strategies for the production of the renewable polymers. This article also gives a snapshot on the challenges of LA-based polymer production and future perspectives on their production.

\section{BIODEGRADABLE BIOPOLYESTERS: PHAS AND PLA}

Among the well-studied biopolyesters are PHAs and PLA. These polyesters are biodegradable and have thermoprocessibility and flexible mechanical properties similar to conventional plastics such as PP and low-density polyethylene (Castro-Aguirre et al., 2016; Shi et al., 2020).

\section{Polyhydroxyalkanoates}

Polyhydroxyalkanoates are a large family of biopolyesters produced by many bacteria for carbon and energy storage (Możejko-Ciesielska and Kiewisz, 2016). Polyhydroxybutyrate (PHB) was the first to be discovered and is the most studied PHA member (Anjum et al., 2016). More than 150 hydroxyalkanoic acid monomer structures have been reported in PHAs (Raza et al., 2018; Sagong et al., 2018; Surendran et al., 2020). The diversity of monomeric structures gives flexible properties of PHAs such as brittleness, elasticity, and stickiness (Raza et al., 2018). PHAs can be produced by either the wild-type, pure/mixed bacteria or by metabolically engineered bacteria including Ralstonia eutropha, Wautersia eutropha, Corynebacterium glutamicum, Azotobacter sp., Bacillus sp., Pseudomonas sp., Burkholderia sp., Halomonas sp., Aeromonas sp., Rhodobacter sphaeroides, and Escherichia coli, among others (Song et al., 2012; Anjum et al., 2016). PHAs are intracellularly accumulated and can be extracted from cells by organic solvents such as chloroform or by use of alkaline 
solutions among other methods (Raza et al., 2018). In the recent past, PHA production has been significantly improved through process optimization and metabolic engineering strategies targeting higher yields/productivity and adjustable monomer structures or monomer ratios in the end products (PHAs; Zhang et al., 2020). In addition, system-level analysis has enabled deeper understanding of microbes producing PHA. These studies, along with construction of new PHA production systems, has led to the synthesis of novel PHAs incorporating new monomers, PHAs with variable monomer composition, and regulation of the molecular mass (Koller and Braunegg, 2018).

\section{Polylactic Acid}

Polylactic acid is a linear aliphatic polyester produced from renewable carbon sources that possesses desirable properties, making it an attractive alternative to the petroleum-derived plastics (Mehta et al., 2005; Castro-Aguirre et al., 2016). Currently, PLA is produced by solvent-based condensation but more commonly by ROP (Figure 2) through the cyclic intermediate dimer (lactide; Pretula et al., 2016; Singhvi et al., 2019). Condensation produces only low- to intermediatemolecular-weight PLA polymers and is carried out using a solvent and at high vacuum and temperature (Auras et al., 2004). The condensation process for PLA synthesis further requires a large reactor and a number of energy-intensive processes such as evaporation and solvent recovery (Mehta et al., 2005). Because of the challenges with condensation, efforts for PLA production shifted to ROP, and Mitsui Toatsu Chemicals patented an azeotropic distillation process that uses a high-boiling solvent to remove water in a direct esterification process to produce high-molecular-weight PLA. This process was adopted by NatureWorks LLC, a global PLA producer to produce high-molecular weight PLA via ROP for commercial purposes (Castro-Aguirre et al., 2016). With the use of ROP and advances in technology of fermentative LA production, the cost of PLA has come down (Hu et al., 2016). However, compared with petroleum-derived plastic counterparts, the multistep chemobio process for PLA production is still complex and expensive, giving PLA a competitive disadvantage (Matsumoto and Taguchi, 2010; Lasprilla et al., 2012; Nduko et al., 2013b; Vink and Davies, 2015; De Clercq et al., 2018). Attempts have been made to alter properties of PLA via blending or copolymerization with other monomers (Matsumoto et al., 2013). Nevertheless, availability of readily polymerizable monomers and their high cost render chemical synthesis of PLA to be unattractive, hence the need for a microbial process for the synthesis of PLA (Singhvi et al., 2019).

\section{THE FIRST MICROBIAL FACTORY OF LA-BASED POLYMERS}

The polymerization of LA monomer in a similar version as PHA synthesis was first proposed by Steinbüchel and Valentin (1995). This was based on the similarity between LA and

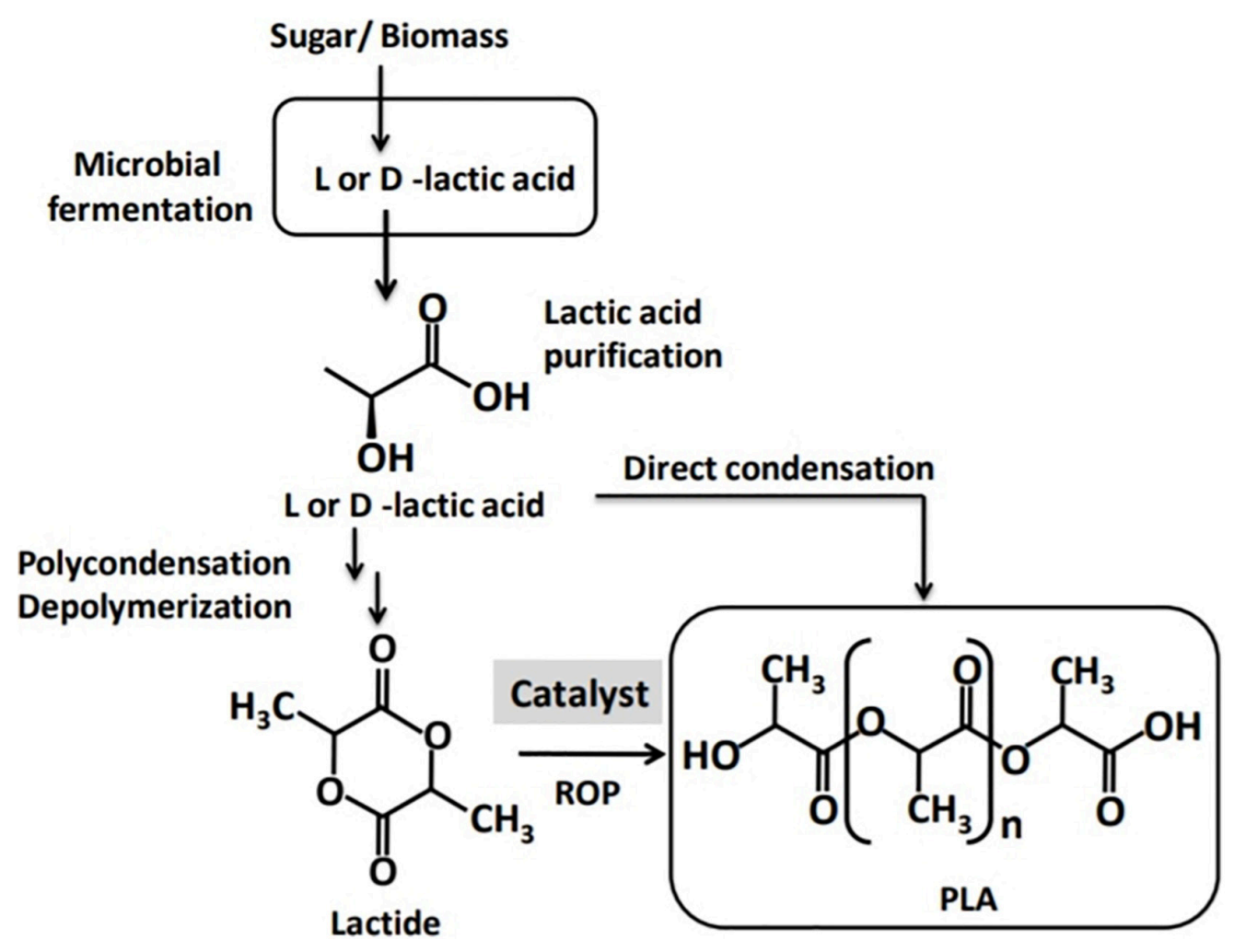

FIGURE 2 | A schematic presentation of polylactic acid (PLA) production from lactic acid by ring-opening polymerization (ROP) and direct condensation. 
PHA monomers, i.e., the presence of carboxyl and hydroxyl groups. However, by 1995 no LA incorporation in PHAs had been reported (Taguchi et al., 2008). The establishment of a single-step process for the production of PLA in a similar version as PHAs will overcome the use of metal catalysts and purification of LA steps in PLA synthesis and potentially reduce the cost of production (Matsumoto and Taguchi, 2013b; Nduko et al., 2013b; Singhvi et al., 2019). In the year 2008, Taguchi et al. (2008) reported for the first time a whole-cell bioprocess for the production of LA-based PHAs: poly(lactateco-3-hydroxybutyrate) $[\mathrm{P}(\mathrm{LA}-c o-3 \mathrm{HB})]$ in engineered bacteria (E. coli; Figure 3). The system employed the PHA biosynthetic metabolic pathway (Figure 4) using an "LA-polymerizing enzyme (LPE)," replacing the metal catalyst used in the chemical synthesis of PLA as earlier explained (Taguchi et al., 2008). The polymerization of the LA unit was possible after the discovery of a Ser325Thr/Glu481Lys mutant of PHA synthase from Pseudomonas sp. 61-3 [PhaC1PS(ST/QK)] that had acquired LApolymerizing activity and a propionate CoA-transferase (PCT) enzyme that was supplying the monomer, D-lactyl-CoA. This discovery laid the foundation for the advancement of the system by varying monomer ratios and composition (Nduko et al., 2015; Nduko and Taguchi, 2019). Subsequently, a similar procedure using an evolved PHA synthase and PCT has been recruited by other researchers to produce LA-based polyesters in engineered microorganisms (Yang et al., 2013; Choi et al., 2019; Tran and Charles, 2020).

\section{Production of LA-Based Polymers With Varied LA Fraction}

In the first report of LA-based $\mathrm{P}(\mathrm{LA}-\mathrm{co}-3 \mathrm{HB})$ biosynthesis using glucose as a carbon source, only $6 \mathrm{~mol} \%$ of LA unit was incorporated into the $\mathrm{P}(\mathrm{LA}-\mathrm{co}-3 \mathrm{HB})$ copolymer (Taguchi et al., 2008). From literature, it is known that monomer ratio, composition, and distribution in a polymeric molecule affect the mechanical, thermal, optical, and chemical properties of a copolymer because of the changed melting temperatures $\left(T_{\mathrm{m}}\right)$ and crystallinity (Menges et al., 2011; Yamada et al., 2011). This was demonstrated by $\mathrm{P}(6 \mathrm{~mol} \% \mathrm{LA}-\mathrm{co}-94 \mathrm{~mol} \% 3 \mathrm{HB})$ that had lower $T_{\mathrm{m}}$ compared with $\mathrm{P}(3 \mathrm{HB})$ and PLA homopolymers (Taguchi et al., 2008). Therefore, monomer ratio, composition, and distribution within a copolymer can be varied to generate new materials (Yamada et al., 2009, 2010; Song et al., 2012; Nduko et al., 2015). In an in vitro chemoenzymatic experiment, P(LA-co$3 \mathrm{HB}$ ) containing $36 \mathrm{~mol} \%$ of LA was produced from equimolar quantities of LA-CoA and 3HB-CoA monomers (Tajima et al., 2009), which was higher than the $6 \mathrm{~mol} \%$ achieved in an in vivo system in engineered E. coli JM109 strain (Taguchi et al., 2008). This suggested that the in vivo system can be rewired to synthesize LA-based polymers with enhanced LA units or

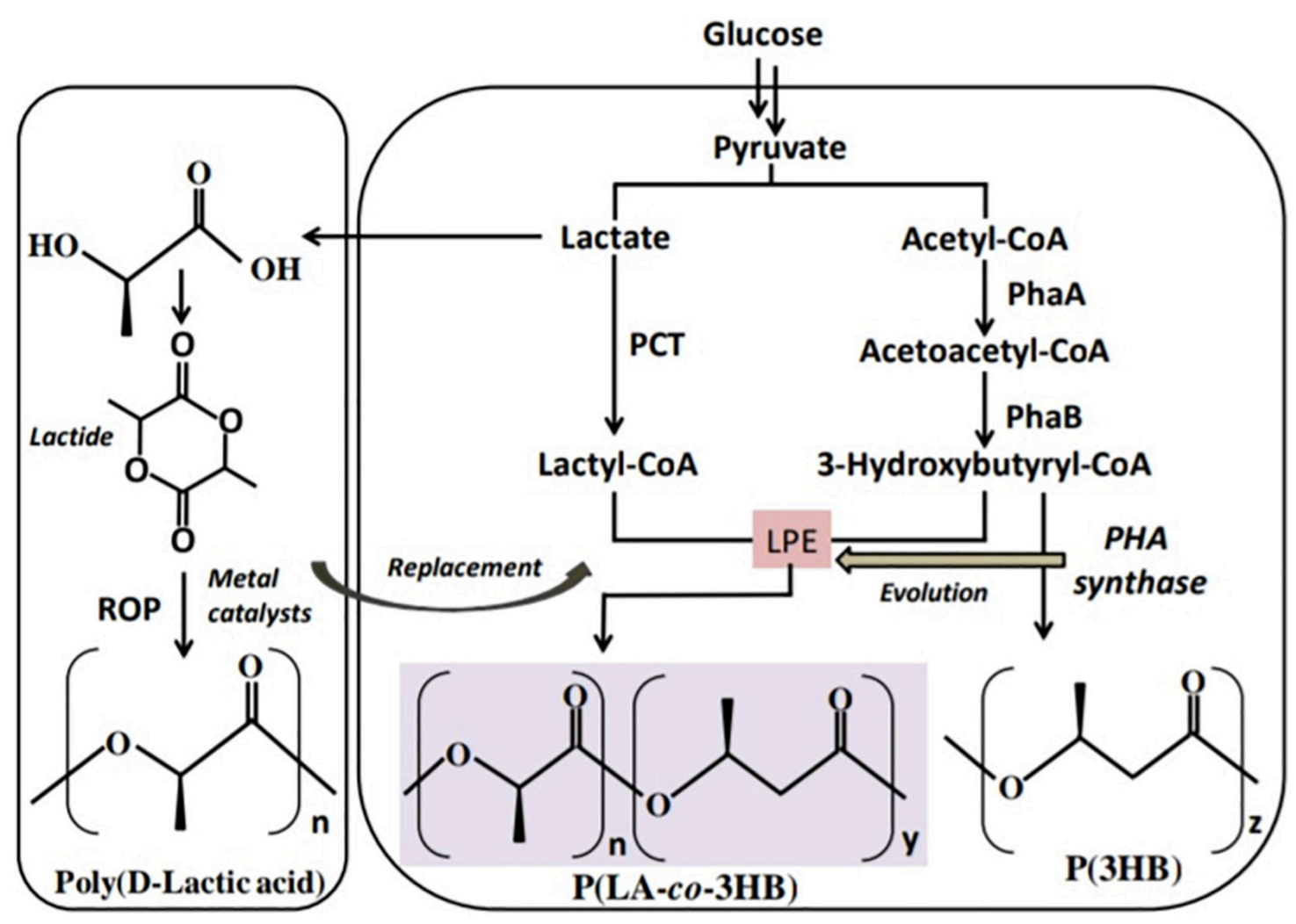

FIGURE 3 | Schematic presentation of the biosynthetic pathway for the production of lactate-based polymers in engineered microorganisms. PCT, propionyl-CoA trabnsferase; PhaA, $\beta$-ketothiolase; PhaB, NADPH-dependent acetoacetyl-CoA reductase; LPE, lactate (LA)-polymerizing enzyme. 


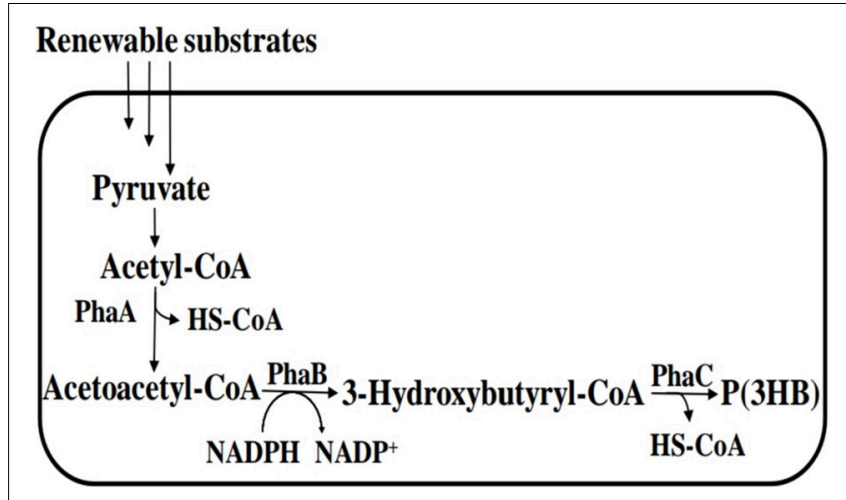

FIGURE 4 | PHA biosynthetic pathway for polyhydroxybutyrate $[\mathrm{P}(3 \mathrm{HB})]$. PhaA, $\beta$-ketothiolase; PhaB, NADPH-dependent acetoacetyl-CoA reductase; and PhaC, polyhydroxyalkanoate (PHA) syynthase.

PLA. Following these pioneering studies by Taguchi et al. (2008), various efforts have been made to alter monomer ratio and composition as summarized in Table $\mathbf{1}$.

Among the strategies employed to enhance LA units in P(LAco-3HB) was the usage of a $\triangle p f l A$ mutant (E. coli JW0885;
Shozui et al., 2010b). The mutant overproduces LA and its usage as a host expressing the set of enzymes for $\mathrm{P}(\mathrm{LA}-\mathrm{co}-3 \mathrm{HB})$ synthesis resulted in the production of $\mathrm{P}(\mathrm{LA}-\mathrm{co}-3 \mathrm{HB})$ with $26.7 \mathrm{~mol} \%$ LA and a polymer content of $51 \%$. Both the LA fraction and polymer content attained by the E. coli JW0885 were higher compared with those of E. coli JM109 (6 mol\% and $40 \%$ for LA and polymer content, respectively). This metabolic engineering strategy was thus effective in enhancing both the LA fraction in the copolymer and the polymer content. The same E. coli mutant (E. coli JW0885) was cultivated under anaerobic conditions, and this led to the production of $\mathrm{P}(\mathrm{LA}-\mathrm{co}-3 \mathrm{HB})$ containing $47 \mathrm{~mol} \%$ LA units (Yamada et al., 2009). This higher LA fraction was, however, at the expense of polymer content as polymer content of the cells was $15 \%$. This called for further interventions to improve the LA fractions in the copolymer without reducing the polymer content in the cells.

In subsequent studies, LPE was further evolved (eLPE) based on beneficial mutations (Chek et al., 2019) and expressed in E. coli JW0885 along with the other requisite $\mathrm{P}(\mathrm{LA}-$ co-3HB) synthesis enzymes. This strategy resulted in the production of $\mathrm{P}(\mathrm{LA}-\mathrm{co}-3 \mathrm{HB})$ having $45 \mathrm{~mol} \% \mathrm{LA}$ units with a polymer content of $62 \%$ from glucose (Yamada et al., 2010). When the culture condition was switched to anaerobic, $\mathrm{P}(\mathrm{LA}-\mathrm{co}-3 \mathrm{HB})$ copolymer

TABLE 1 | History of microbial LA-based polymer production.

\section{Intervention}

First synthesis of LA-based polymer: $\mathrm{P}(\mathrm{LA}-\mathrm{CO}-3 \mathrm{HB})$

Use of $\Delta p f I A$ mutant (Escherichia coli JW0885) with $\mathrm{P}(\mathrm{LA}-\mathrm{CO}-3 \mathrm{HB}$ ) biosynthetic pathway

Use of $\Delta$ pflA mutant (E. coli JW0885) with $\mathrm{P}(\mathrm{LA}-\mathrm{CO}-3 \mathrm{HB})$ biosynthetic pathway under anaerobic conditions

Use of $\triangle p$ flA mutant (E. coli JW0885) with $\mathrm{P}(\mathrm{LA}-\mathrm{CO}-3 \mathrm{HB})$ biosynthetic pathway having an evolved LPE (eLPE) under aerobic conditions

Use of $\triangle p$ flA mutant (E. coli JW0885) with $\mathrm{P}(\mathrm{LA}-\mathrm{CO}-3 \mathrm{HB})$ biosynthetic pathway having an evolved LPE (eLPE) under anaerobic conditions

Use of E. coli LS5218 expressing evolved LPE on glucose supplemented with valerate under aerobic conditions. $\mathrm{P}(3 \mathrm{HB})$ biosynthetic pathway was omitted Corynebacterium glutamicum Expressing LPE only/and PHB biosynthetic pathway under aerobic conditions on glucose

E. coli JW0885 ( $\triangle$ pfIA) expressing LPE and PHB biosynthetic pathway and cultivated on xylose under aerobic conditions

E. coli JW0885 ( $\triangle$ pfIA) expressing evolved LPE (eLPE) and PHB biosynthetic pathway and cultivated on xylose under aerobic conditions

E. coli JW2121 ( $\Delta d l d$ ) expressing evolved LPE (eLPE) and PHB biosynthetic pathway and cultivated on xylose under aerobic conditions

E. coli JWMB1 ( $\Delta$ dld, $\Delta$ pfIA) expressing evolved LPE (eLPE) and PHB biosynthetic pathway and cultivated on xylose under aerobic conditions In vitro analysis of the $\mathrm{P}(\mathrm{LA}-\mathrm{CO}-3 \mathrm{HB})$ biosynthetic system in $E$. coli and C. glutamicum

Expression of medium chain length (MCL)-supplying enzymes (PhaG and (R)-3-hydroxyacyl-CoA ligase in E. coli along with LPE

Expression of exogenous of D-lactate dehydrogenase (IdhD) from Lactobacillus acetotolerans $\mathrm{HT}$ in E. coli harboring $\mathrm{P}(\mathrm{LA}-\mathrm{CO}-3 \mathrm{HB})$ biosynthetic genes

Expression of PCT and PhaC1400 in Sinorhizobium meliloti

\section{Achieved results}

LA-based polymer synthesis with 6 mol\% LA

Production of $\mathrm{P}(\mathrm{LA}-\mathrm{CO}-3 \mathrm{HB})$ containing $26 \mathrm{~mol} \%$ from glucose

Production of $\mathrm{P}(\mathrm{LA}-\mathrm{CO}-3 \mathrm{HB})$ containing

$47 \mathrm{~mol} \%$ from glucose but with polymer content less than $2 \%$ of dry cell weight

Production of $\mathrm{P}(\mathrm{LA}-\mathrm{CO}-3 \mathrm{HB})$ containing

$47 \mathrm{~mol} \%$ from glucose with polymer content

less than $60 \%$ of dry cell weight

Production of $\mathrm{P}(\mathrm{LA}-\mathrm{CO}-3 \mathrm{HB})$ containing

62 mol\% from glucose but with polymer content less than $1 \%$ of dry cell weight

Production of LA-based polymer containing 90-96 mol\% LA units

Production of $\mathrm{P}(\mathrm{LA}-\mathrm{CO}-3 \mathrm{HB})$ containing 97-99.3 mol\% LA units

Production of $\mathrm{P}(\mathrm{LA}-\mathrm{CO}-3 \mathrm{HB})$ containing $34 \mathrm{~mol} \%$ from xylose

Production of $\mathrm{P}(\mathrm{LA}-\mathrm{CO}-3 \mathrm{HB})$ containing $60 \mathrm{~mol} \%$ from xylose

Production of $\mathrm{P}(\mathrm{LA}-\mathrm{CO}-3 \mathrm{HB})$ containing $66 \mathrm{~mol} \%$ from xylose

Production of $\mathrm{P}(\mathrm{LA}-\mathrm{CO}-3 \mathrm{HB})$ containing

$73 \mathrm{~mol} \%$ from xylose

Production of PLA homopolymer

Production of $L A$-based polymers with $\mathrm{MCL}$ $3 \mathrm{HA}$ units with $\mathrm{C}_{3}, \mathrm{C}_{8}, \mathrm{C}_{10}$, and $\mathrm{C}_{12}$ monomers with 92 mol\% LA

Produced $\mathrm{P}(\mathrm{LA}-\mathrm{CO}-3 \mathrm{HB})$ with high $\mathrm{LA}$ fractions compared with control cells

Production of PLA homopolymer

\section{References}

Taguchi et al., 2008

Yamada et al., 2009

Yamada et al., 2009

Yamada et al., 2010

Yamada et al., 2010

Shozui et al., 2011

Song et al., 2012

Nduko et al., $2013 a$

Nduko et al., $2013 a$

Nduko et al., 2014

Nduko et al., 2014

Matsumoto et al., 2018b

Goto et al., 2019a

Goto et al., 2019b

Tran and Charles, 2020 
with 62 mol\% LA unit was produced, however, with polymer content in dry cells being 12\% (Yamada et al., 2010). The results demonstrated the power of evolutionary engineering in affecting enzyme specificity and activity.

When $\mathrm{P}(\mathrm{LA}-\mathrm{co}-3 \mathrm{HB})$ monomer sequence was analyzed by nuclear magnetic resonance (NMR), the LA-LA-LA triad sequence was detected (Yamada et al., 2009). This suggested that LA monomer could link to another LA monomer, implying that an LA-rich P(LA-co-3HB) or PLA could be synthesized by microorganisms, although the earlier in vitro experiment had indicated that LA polymerization was dependent on the presence of 3HB monomer (Taguchi et al., 2008). Shozui et al. (2011) knocked out PhaA and $\mathrm{PhaB}$ (3HB-CoA monomer supplying enzymes) from the $\mathrm{P}(\mathrm{LA}-\mathrm{co}-3 \mathrm{HB})$ biosynthesis construct to eliminate $3 \mathrm{HB}$ supply and instead expressed PhaJ, which could supply $3-\mathrm{HV}-\mathrm{CoA}$ from valerate added to the media through the $\beta$-oxidation pathway. The E. coli JW0885 cells with that system produced $\mathrm{P}(\mathrm{LA}-\mathrm{co}-3 \mathrm{HB}-\mathrm{co}-3 \mathrm{HV})$ with $90-96 \mathrm{~mol} \%$ of LA units from glucose supplemented with sodium valerate. Although $3 \mathrm{HB}$ was incorporated into the formed polymer, this demonstrated that elimination of the $3 \mathrm{HB}$ supply pathway was a viable strategy for producing PLA-like polymers.

\section{Production of LA-Based Polymers in Other Microorganisms}

Production of LA-based polymers in engineered E. coli was thought to harbor challenges as the organism being a Gramnegative bacterium produces harmful endotoxins such as lipopolysaccharides (Lee et al., 2015; Mamat et al., 2015; Grage et al., 2017). This is challenging especially if the polymers are targeted for food-grade contact surfaces and in biomedical applications (Taguchi et al., 2015). C. glutamicum, an endotoxinfree Gram-positive bacterium with GRAS (generally recognized as safe) status that had been applied for the biosynthesis of a number of industrial compounds and PHAs, was selected as host for the production of LA-based polymers (Jo et al., 2006, 2007; Taguchi et al., 2015). Consequently, the requisite P(LA-co-3HB) synthesis pathway was assembled in C. glutamicum and the host cultivated for polymer production from glucose. In stark contrast with E. coli ( $45 \mathrm{~mol} \%$ of LA, $62 \%$ polymer content), the P(LAco-3HB) produced in C. glutamicum had $97 \mathrm{~mol} \%$ of LA fraction and $2.4 \%$ polymer content with the same set of genes (Song et al., 2012). The high LA fraction in C. glutamicum was attributed to the low 3HB-CoA supply in C. glutamicum as supported by low $\mathrm{P}(3 \mathrm{HB})$ yield in C. glutamicum (1.0\%) when PCT (DLA-CoA supplying enzyme) was omitted from the system. To corroborate this, the researchers omitted PhaA and PhaB (3-HBCoA supplying enzymes) from the system (Song et al., 2012). Expressing $\mathrm{P}(\mathrm{LA}-\mathrm{co}-3 \mathrm{HB})$ synthetic system without $\mathrm{PhaA}$ and $\mathrm{PhaB}$ in C. glutamicum resulted in the production of PLA-like polymers $[\mathrm{P}(99.3 \mathrm{~mol} \% \mathrm{LA}-\mathrm{co}-3 \mathrm{HB})]$ with a polymer content of $1.4 \%$. The detection of $3 \mathrm{HB}$ units in the resultant $\mathrm{P}(\mathrm{LA}-\mathrm{co}-3 \mathrm{HB})$ was attributed to the possible presence of an endogenous 3-HBCoA supplying pathway in C. glutamicum. ${ }^{1} \mathrm{H}-\mathrm{NMR}$ analysis of $\mathrm{P}(99.3 \mathrm{~mol} \% \mathrm{LA}-\mathrm{co}-3 \mathrm{HB})$ produced in C. glutamicum detected strong resonances of LA that were similar to those of chemically synthesized PLA (Song et al., 2012).

To increase polymer productivity in C. glutamicum, Matsumoto et al. (2014) explored the rate-limiting step by quantitative metabolite analysis. Significant quantities of lactylCoA were found during polymer synthesis, indicating that rate limitation occurred during polymerization. Subsequently, codon optimization of LPE was conducted to increase its expression level, and this led to a 4.4-fold increase in polymer content compared with the control without significantly affecting lactyl-CoA concentration. In the same study, it was found that acetyl-CoA served as a CoA donor for lactyl-CoA. The study demonstrated the significant of metabolite analysis to improve PLA-like polymer production.

When the polymers produced in C. glutamicum and E. coli were assessed, it was found that LPE could produce PLA by polymerizing LA-CoA as a sole substrate (Matsumoto et al., 2018b). However, the PLA had low molecular weight that was attributed to the low mobility of the synthesized polymer. It was found that polymerization of LA-CoA and 3-HB-CoA proceeded, dependent on the 3 -LA-CoA concentration in the bacterium. For instance, the LA-CoA concentrations in bioengineered C. glutamicum were high and detectable, unlike in E. coli where LA-CoA concentrations were undetectable. Consequently, where there was low LA-CoA concentration in E. coli, $\mathrm{P}(\mathrm{LA}-\mathrm{co}-3 \mathrm{HB})$ synthesis proceeded more efficiently than in C. glutamicum that had high levels of LA-CoA. These results demonstrated the importance of genetic diversity in varying monomer ratios in P(LA-co-3HB; Song et al., 2015).

In another study, Tran and Charles (2020) introduced a broadhost-range plasmid (pTAM) that was expressing codon optimized PCT and engineered Pseudomonas sp. MBEL 6-19 PHA synthase 1 (PhaC1Ps6-19, PhaC1400) into phaC mutant strains of Sinorhizobium meliloti and P. putida, which are native PHA producers. S. meliloti was found to produce PLA homopolymer with $3.2 \%$ polymer content, while $P$. putida produced copolymers containing $3 \mathrm{HB}, 3 \mathrm{HHx}$, and $3 \mathrm{HO}$ with polymer content of up to $42 \%$. These results indicated that exploration of host strains offers another strategy for the production of LA-based polymers and PLA.

\section{Latest Approaches to LA-Based Polymer Production}

To further modulate $\mathrm{P}(\mathrm{LA}-\mathrm{co}-3 \mathrm{HB})$ yield and monomer composition, other strategies were devised. One such strategy was the disruption of $\sigma$ factors that govern gene transcription at the global level. Four $\sigma$ factors, RpoS, RpoN, FliA, and FecI, which are found in $E$. coli, were disrupted and the respective disruptant mutants used for $\mathrm{P}(\mathrm{LA}-\mathrm{co}-3 \mathrm{HB})$ synthesis (Kadoya et al., 2015a). It was found that $\Delta r p o N$ mutant had enhanced LA fraction $(26.2 \mathrm{~mol} \%)$ and polymer yield $(6.2 \mathrm{~g} / \mathrm{L})$ when compared with the parent E. coli strain (E. coli BW25113; 18.6\% mol\% and $5.3 \mathrm{~g} / \mathrm{L}$ for LA fraction and polymer yield, respectively). These beneficial effects in the $\Delta r p o N$ mutant were attributed to higher LA production in the mutant strain. The $\Delta r p o S$ mutant on its part produced higher $\mathrm{P}(\mathrm{LA}-\mathrm{co}-3 \mathrm{HB} ; 5.8 \mathrm{~g} / \mathrm{L})$ but had 
lower LA fraction (12.3 mol\%) than that of E. coli BW25113 (parent strain; $18.6 \mathrm{~mol} \%$ ). The $\Delta$ rpoN mutant was grown in xylose that had been demonstrated to give higher LA fraction than glucose for $\mathrm{P}(\mathrm{LA}-\mathrm{co}-3 \mathrm{HB})$ production (Nduko et al., 2013a, 2014). The $\mathrm{P}(\mathrm{LA}-\mathrm{co}-3 \mathrm{HB})$ polymer produced with this mutant had 33.9 mol\% LA that was higher than $26.2 \mathrm{~mol} \%$ LA in the polymers produced from glucose by the same mutant (Kadoya et al., 2015b). However, the LA ratios in $\mathrm{P}(\mathrm{LA}-\mathrm{co}-3 \mathrm{HB})$ produced by $\triangle r p o N$ mutant cultivated on xylose $(33.9 \mathrm{~mol} \%)$ were similar to those produced by the parent strain (BW25113) cultivated under the same conditions ( $35.9 \mathrm{~mol} \%$ ), indicating no synergistic effects between rpoN disruption and xylose utilization.

Genome-wide transposon mutagenesis of $\mathrm{P}(\mathrm{LA}-\mathrm{co}-3 \mathrm{HB})-$ producing $E$. coli was conducted as another strategy to generate beneficial mutants for $\mathrm{P}(\mathrm{LA}-\mathrm{co}-3 \mathrm{HB})$ production (Kadoya et al., 2015b). From more than 10,000 mutants generated, a mutant $(\triangle m \operatorname{tg} A)$ was generated that produced significantly higher $(5.1 \mathrm{~g} / \mathrm{L}) \mathrm{P}(\mathrm{LA}-\mathrm{co}-3 \mathrm{HB})$ than the recombinant parent strain $(2.9 \mathrm{~g} / \mathrm{L})$. The $\triangle m \operatorname{tg} A$ strain was found to be enlarged in size during $\mathrm{P}(\mathrm{LA}-\mathrm{co}-3 \mathrm{HB})$ production, and this mutation in $E$. coli BW25113 (JW3175) was evaluated for $\mathrm{P}(\mathrm{LA}-\mathrm{co}-3 \mathrm{HB})$ production (Kadoya et al., 2015c). The $\Delta m t g A$ mutation was found to be effective in $\mathrm{P}(\mathrm{LA}-\mathrm{co}-3 \mathrm{HB})$ accumulation $(7.0 \mathrm{~g} / \mathrm{L})$ as compared with its parental strain, E. coli BW25113 (5.2 g/L), without significant alteration of the $\mathrm{LA} / 3 \mathrm{HB}$ ratio. This mutation gave flexibility for expansion during polymer production and thus along with $\triangle r p o N$ offers an additional strategies for $\mathrm{P}(\mathrm{LA}-\mathrm{co}$ $3 \mathrm{HB})$ production.

To enhance LA fraction in $\mathrm{P}(\mathrm{LA}-c o-3 \mathrm{HB})$, Goto et al. (2019b) introduced exogenous D-lactate dehydrogenase gene (ldhD) from Lactobacillus acetotolerans HT into E. coli strains expressing $\mathrm{P}(\mathrm{LA}-\mathrm{co}-3 \mathrm{HB})$ biosynthetic genes. The recombinant strains cultivated on glucose under microaerobic conditions produced $\mathrm{P}(\mathrm{LA}-\mathrm{co}-3 \mathrm{HB})$ copolymer with LA fractions of 19.8, 15.7, and $28.5 \mathrm{~mol} \%$ for DH5 $\alpha$, LS5218, and XL1-Blue E. coli strains, respectively. These values were higher than those of corresponding strains without the ldhD gene $(<6.7 \mathrm{~mol} \%$ of LA units). This demonstrated $\mathrm{ldhD}$ gene expression as an additional strategy to enhance LA-fraction in $\mathrm{P}(\mathrm{LA}-\mathrm{co}-3 \mathrm{HB})$.

There have been attempts to diversify monomers copolymerizing with LA apart from 3HB. For instance, Shozui et al. (2010a) produced a terpolymer that incorporated up to $7.2 \mathrm{~mol} \% 3 \mathrm{HV}$ together with $8.7 \mathrm{~mol} \% \mathrm{LA}$ and $84.2 \mathrm{~mol} \% 3 \mathrm{HB}$. Matsumoto et al. (2013) produced a lactate-based copolymer containing $2 \mathrm{HB}$ in $E$. coli. In the study, recombinant $E$. coli LS5218 expressing LPE and PCT were cultivated in a medium containing glucose and 2HB-produced $\mathrm{P}(86 \mathrm{~mol} \% 2 \mathrm{HB}$ co-LA) copolymer. Goto et al. (2019a) produced LA-based polymers containing medium-chain-length 3-hydroxyalkanoates (MCL-3HA) in E. coli. The E. coli LS5218 strain expressing P(LAco-3HB) biosynthetic genes along with (MCL-3HA) monomer supplying enzymes [(R)-3-hydroxyacyl-ACP thioesterase (PhaG) and $(R)$-3-hydroxyacyl (3HA)-CoA ligase] from the fatty acid biosynthesis pathway produced $\mathrm{P}(\mathrm{LA}-\mathrm{co}-3 \mathrm{HB}-\mathrm{co}-3 \mathrm{HA})$, a copolymer containing $19.7 \mathrm{~mol} \% \mathrm{LA}\left(\mathrm{C}_{3}\right), 74.9 \mathrm{~mol} \% 3 \mathrm{HB}\left(\mathrm{C}_{4}\right)$, and $5.4 \mathrm{~mol} \% \mathrm{MCL}-3 \mathrm{HA}$ units of $\mathrm{C}_{8}$ and $\mathrm{C}_{10}$. When PhaA and $\mathrm{PhaB}$ (3HB supplying enzymes) were excluded from the system,
$\mathrm{P}\left(92.0 \%\right.$ LA-co-3HA) with an $\mathrm{HA}$ containing $\mathrm{C}_{3}, \mathrm{C}_{8}, \mathrm{C}_{10}$, and $\mathrm{C}_{12}$ monomers was produced. This copolymer had transparency similar to that of chemically synthesized PLA (Goto et al., 2019a). Other monomers that have been incorporated along with lactate to form copolymers include glycolate (Choi et al., 2016) and 4HB (Choi et al., 2020).

\section{APPLICATION OF LIGNOCELLULOSIC BIOMASS FOR THE PRODUCTION OF $\mathrm{P}$ (LA-CO-3HB)}

\section{Xylose Utilization for Production of P(LA-Co-3HB)}

The substrate to use for $\mathrm{P}(\mathrm{LA}-\mathrm{co}-3 \mathrm{HB})$ production is important because of the cost implication (substrate can take up to $50 \%$ of total production cost; Raza et al., 2018) and its effect on the polymer/copolymer composition (Alcântara et al., 2020). Substrates such as sugars and starch-based substrates are edible and in direct competition with foods and feeds, and thus, the use of the second generation feedstock is essential. This is from the ethical standpoint and the need to prevent increase in food prices and disrupting global food supplies (Koller and Braunegg, 2018). Therefore, there has been efforts by scientists to valorize waste streams as carbon sources for the production of PHAs, which aligns with the biorefinery concept (Al-Battashi et al., 2019). Lignocellulosic biomass is inedible and has demonstrated great potential as a carbon source for PHA production (Matsumoto et al., 2011b; Nduko et al., 2012b; Bhatia et al., 2019; Li and Wilkins, 2020). Lignocellulosic biomass comprises 40-50\% cellulose, 25-30\% hemicellulose, and 15-20\% lignin (Brethauer and Studer, 2015). The cellulose component has been hydrolyzed into glucose and used for the fermentative production of a number of bioproducts. In contrast, the hemicellulose components composed of mainly xylose and the lignin component have not been fully utilized (Pollegioni et al., 2015; Takkellapati et al., 2018; Xu et al., 2020). In a biorefinery where lignocellulosic biomass is utilized, it is essential to fully utilize cellulose and hemicellulose (carbohydrate components) and lignin.

To demonstrate the potential of hemicellulose, Nduko et al. (2013a) evaluated the use of pure xylose for P(LA-co-3HB) production. Using E. coli JW0885 $\left(p f A^{-}\right)$transformed with requisite enzymes for $\mathrm{P}(\mathrm{LA}-\mathrm{co}-3 \mathrm{HB})$ synthesis (LPE along with the $3 \mathrm{HB}-\mathrm{CoA}$ and LA-CoA monomer supplying enzymes), $\mathrm{P}(34 \mathrm{~mol} \% \mathrm{LA}-\mathrm{co}-3 \mathrm{HB})$ with $61 \%$ polymer content and $5.5 \mathrm{~g} / \mathrm{L}$ polymer yield was produced from $20 \mathrm{~g} / \mathrm{L}$ of xylose. This was different from $\mathrm{P}(26 \mathrm{~mol} \% \mathrm{LA}-\mathrm{co}-3 \mathrm{HB})$ with $62 \%$ polymer content and $6.5 \mathrm{~g} / \mathrm{L}$ polymer yield obtained from $20 \mathrm{~g} / \mathrm{L}$ of glucose under the same cultivation conditions (Yamada et al., 2009; Nduko et al., 2013a). When eLPE was employed, E. coli JW0885 cells cultivated on $20 \mathrm{~g} / \mathrm{L}$ of xylose produced $\mathrm{P}(60 \mathrm{~mol} \% \mathrm{LA}-\mathrm{co}-3 \mathrm{HB})$ with a polymer content of $70 \%$ and polymer yield of $7.3 \mathrm{~g} / \mathrm{L}$, whereas those cultivated in $20 \mathrm{~g} / \mathrm{L}$ of glucose produced $\mathrm{P}(47 \mathrm{~mol} \% \mathrm{LA}-\mathrm{co}$ $3 \mathrm{HB}$ ) with a polymer content of $81 \%$ and polymer yield of $7.9 \mathrm{~g} / \mathrm{L}$ (Nduko et al., 2013a). Xylose thus demonstrated its advantages 
in giving $\mathrm{P}(\mathrm{LA}-c o-3 \mathrm{HB})$ with LA fractions $>50 \%$ with high cellular polymer content and yield, which were impossible with glucose that gave low polymer yields $(<1 \mathrm{~g} / \mathrm{L})$ from $20 \mathrm{~g} / \mathrm{L}$ under anaerobic conditions (Yamada et al., 2010). Gene disruptants ( $\Delta p t a, \Delta a c k A, \Delta p o x B$, and $\Delta d l d$ ) that had been demonstrated to increase LA yield in E. coli (Zhou et al., 2011) were transformed with the set of genes for $\mathrm{P}(\mathrm{LA}-\mathrm{co}-3 \mathrm{HB})$ production and cultivated on xylose (Nduko et al., 2014). The $\Delta p t a, \Delta a c k A$, and $\Delta$ dld mutants had higher polymer yields (6.5-7.4 g/L) compared with $6.3 \mathrm{~g} / \mathrm{L}$ of the parent strain (E. coli BW25113). The $\Delta p t a$ and $\Delta$ dld mutants also had higher LA fractions (58 and $66 \mathrm{~mol} \%$, respectively) in $\mathrm{P}(\mathrm{LA}-\mathrm{co}-3 \mathrm{HB})$ compared with $56 \mathrm{~mol} \%$ for the E. coli BW25113 (parent strain). When the $\Delta p f l A$ and $\Delta d l d$ mutations were combined, dual benefits were realized, i.e., high LA fraction $(73 \mathrm{~mol} \%)$ and high polymer yield $(6.4 \mathrm{~g} / \mathrm{L}$ from $20 \mathrm{~g} / \mathrm{L}$ of xylose) with a polymer content of $96 \%$ (Nduko et al., 2014), underscoring the significance of metabolic engineering in modulating LA fractions in $\mathrm{P}$ (LA-co-3HB).

Another strategy that was used to exploit xylose utilization was the overexpression of the galactitol permease, GatC (Nduko et al., 2014), which is a non-ATP xylose transporter that was shown to transport xylose efficiently during LA production (Utrilla et al., 2012). This was intended to avoid the involvement of the main xylose transporter, xylE, a member of the ATPbinding cassette transporter encoded by the xylFGH operon, hence availing ATP for other cellular activities (Utrilla et al., 2012). E. coli ( $\Delta p f l A)$ harboring $\mathrm{P}(\mathrm{LA}-c o-3 \mathrm{HB})$ production genes and overexpressing GatC produced $8.3 \mathrm{~g} / \mathrm{L}$ of $\mathrm{P}(67 \mathrm{~mol} \% \mathrm{LA}-\mathrm{co}$ $3 \mathrm{HB}$ ) from $20 \mathrm{~g} / \mathrm{L}$ xylose (polymer content $88 \%$ ) compared with $7.7 \mathrm{~g} / \mathrm{L}$ of $\mathrm{P}(58 \mathrm{~mol} \% \mathrm{LA}-\mathrm{co}-3 \mathrm{HB})$ and $79 \%$ polymer content of the parental strain expressing $\mathrm{P}(\mathrm{LA}-\mathrm{co}-3 \mathrm{HB})$ production genes and GatC (Nduko et al., 2014). When xylose amount was doubled $(40 \mathrm{~g} / \mathrm{L})$, the E. coli BW 25113 cells overexpressing GatC produced $14.4 \mathrm{~g} / \mathrm{L}$ of $\mathrm{P}(66 \mathrm{~mol} \% \mathrm{LA}-c o-3 \mathrm{HB})$, the highest amount of polymer produced from pure sugars under the same culture conditions. Strains producing $\mathrm{P}\left(\mathrm{LA}-\mathrm{co}^{-} \mathrm{HHB}\right)$ having high LA fractions were found to have high LA in the medium. Production of $3 \mathrm{HB}$ is less efficient compared with LA. This is because to produce $3 \mathrm{HB}\left(\mathrm{C}_{4}\right)$ from pyruvate, two molecules of pyruvate $\left(\mathrm{C}_{3} \times 2\right)$ are used with a loss of two carbon molecules as $\mathrm{CO}_{2}$, whereas two molecules of pyruvate produce two molecules of LA units $\left(\mathrm{C}_{3} \times 2\right)$. This means that when $\mathrm{P}(\mathrm{LA}-c \mathrm{co}-3 \mathrm{HB})$ with high LA fraction is produced, copolymer yields will be high as well (Nduko et al., 2014). High-cell-density fed-batch fermentation using xylose and/or glucose as the carbon source was evaluated as a strategy to improve polymer production (Hori et al., 2019). In a glucose/xylose switching fermentation method, $\mathrm{P}(\mathrm{LA}-c o-3 \mathrm{HB})$ concentrations of $26.7 \mathrm{~g} / \mathrm{L}$ were attained. This study demonstrated a potential strategy of utilizing glucose and xylose mixture arising from hydrolysis of lignocellulosic biomass that overcomes carbon catabolite repression.

From these studies, a direct relationship between LA production in some strains and LA fraction in the $\mathrm{P}$ (LA-co$3 \mathrm{HB}$ ) was found that indicated carbon redistribution with the mutant strains. In cases where there was incomplete utilization of xylose, LPE polymerization could have been the limiting step. Overexpression of GatC and fed-batch fermentation mode benefited polymer yields. These studies indicated that xylose could be a potent substrate for $\mathrm{P}(\mathrm{LA}-\mathrm{co}-3 \mathrm{HB})$ production. As xylose is a major component of hemicellulose, its utilization could improve the economics of lignocellulose biomass use whereby only glucose is utilized efficiently. It was also demonstrated that fed-batch mode could be efficiently for $\mathrm{P}(\mathrm{LA}-\mathrm{co}-3 \mathrm{HB})$ production from a mixture of glucose and xylose that could arise from lignocellulosic biomass hydrolysis.

\section{Lignocellulosic Biomass Hydrolyzates Use for P(LA-co-3HB) Production}

As the production of $\mathrm{P}(\mathrm{LA}-\mathrm{co}-3 \mathrm{HB})$ from the major lignocellulosic biomass sugars (pure glucose and xylose) had been demonstrated (Yamada et al., 2009; Nduko et al., 2014), efforts were made to produce $\mathrm{P}(\mathrm{LA}-\mathrm{co}-3 \mathrm{HB})$ from biomass hydrolyzate. Sun et al. (2016) hydrolyzed Miscanthus $\times$ giganteus (hybrid Miscanthus) and rice straw using a commercial cellulase enzyme complex into a mixture of glucose and xylose. The hydrolyzates were used as a carbon substrate for $\mathrm{P}(\mathrm{LA}-\mathrm{co}-3 \mathrm{HB})$ synthesis in E. coli BW25113 expressing LPE and 3HB-CoA and LA-CoA monomer supplying enzymes. The E. coli BW25113 growing on the Miscanthus $\times$ giganteus and rice straw hydrolyzates had a higher dry cell weight (9.2 and $9.4 \mathrm{~g} / \mathrm{L}$, respectively) than the same cells cultivated on a mixture of pure glucose and xylose $(8.8 \mathrm{~g} / \mathrm{L})$. This was attributed to the presence of trace amounts of other sugars such as arabinose in the hydrolyzates. However, the polymer contents from the hydrolyzate cultures (56.9\% and $55.9 \%$ for Miscanthus $\times$ giganteus and rice straw, respectively) and the mixture of the pure sugars (56.0\%) were similar, whereas the LA fractions were $8.7 \mathrm{~mol} \%$ for rice straw hydrolyzate, $16.9 \mathrm{~mol} \%$ for Miscanthus $\times$ giganteus hydrolyzate, and $15.6 \mathrm{~mol} \%$ for the glucose-xylose mixture. Glucose exerts carbon catabolite repression in the presence of other sugars, and this could happen in a hydrolyzate containing a mixture glucose and xylose (Ren et al., 2009). Kadoya et al. (2018) achieved simultaneous glucose and xylose utilization in E. coli by overexpressing a gene encoding Mlc, a multiple regulator for xylose and glucose uptake. By overexpressing Mlc, E. coli cells accumulated $13.6 \mathrm{~g} / \mathrm{L}$ of $\mathrm{P}(\mathrm{LA}-\mathrm{co}-3 \mathrm{HB})$ with polymer content of $65 \%$ and LA fraction of $11.8 \mathrm{~mol} \%$, which was higher compared with $4.8 \mathrm{~g} / \mathrm{L}$ of $\mathrm{P}(\mathrm{LA}-\mathrm{co}-3 \mathrm{HB})$ with polymer content of $50 \%$ and LA fraction of $14.4 \mathrm{~mol} \%$ produced by the parental cells without Mlc overexpression (control) from a mixture of glucose and xylose. When the Mlc overexpression E. coli strain was cultivated on Miscanthus $\times$ giganteus hydrolyzate, it produced $10.6 \mathrm{~g} / \mathrm{L} \mathrm{P}(\mathrm{LA}-\mathrm{co}-3-\mathrm{HB})$ with polymer content and LA fraction of $58.6 \%$ and $10.9 \mathrm{~mol} \%$, respectively, which was also higher than $4.4 \mathrm{~g} / \mathrm{L}$ of $\mathrm{P}(\mathrm{LA}-\mathrm{co}-3-\mathrm{HB})$ with polymer content of $47.3 \%$ and LA fraction of $9.1 \mathrm{~mol} \%$ attained by the control cells (not expressing Mlc; Kadoya et al., 2018). These results exhibited the significance of Mlc overexpression in overcoming catabolite repression.

In another study, Takisawa et al. (2017) used eucalyptus hemicellulose hydrolyzate consisting mainly xylose and galactose for $\mathrm{P}\left(\mathrm{LA}-\mathrm{co}_{-} \mathrm{3HB}\right)$ production in E. coli. The dry cell weight attained was $8.6 \mathrm{~g} / \mathrm{L}$, polymer yield $5.4 \mathrm{~g} / \mathrm{L}$, polymer content $62.4 \%$, and LA fraction of $5.5 \mathrm{~mol} \%$, which were comparable 
to those obtained from a mixture of pure xylose and galactose. However, the LA fraction in $\mathrm{P}(\mathrm{LA}-\mathrm{co}-3 \mathrm{HB})$ from the hydrolyzate was lower than that obtained from the pure sugars (16.9 mol\%). The low LA fraction in P(LA-co-3HB) obtained from the hemicellulose hydrolyzate was attributed to catabolite repression in $E$. coli, although the results demonstrated the potential of eucalyptus hemicellulose hydrolyzate for P(LA-co$3 \mathrm{HB})$ production.

During lignocellulose biomass pretreatment, some toxic byproducts such as furfural, hydroxymethylfurfural, and acetate are produced (de Paula et al., 2019). These compounds can affect microbial growth and affect polymer yield when the hydrolyzates are used as substrates for polymer production (Nduko et al., 2012b). As a result, a number of processes have been recruited to detoxify the hydrolyzates before use in fermentation. However, these detoxifying steps add to the overall cost of polymer production. These have triggered the search for resistant organisms. For instance, Salamanca-Cardona et al. (2017) identified E. coli strains that were tolerant to acetate, whereas Nduko et al. (2012b) identified E. coli LS5215 to be resistant to 5-hydroxymethylfurfural. These strains could thus be useful in the production of $\mathrm{P}(\mathrm{LA}-\mathrm{co}-3 \mathrm{HB})$ from lignocellulosic biomass hydrolyzates.

The two-step system of hydrolysis followed by fermentation for the production of $\mathrm{P}(\mathrm{LA}-\mathrm{co}-3 \mathrm{HB})$ could be costly because hydrolysis is done at high temperatures and low $\mathrm{pH}$ using acids or high $\mathrm{pH}$ using alkaline compounds. Therefore, a process that consolidates hydrolysis of biomass and fermentation for the production of $\mathrm{P}(\mathrm{LA}-\mathrm{co}-3 \mathrm{HB})$ could be cost-friendly (Figure 5). E. coli that has been engineered for $\mathrm{P}(\mathrm{LA}-\mathrm{co}-3 \mathrm{HB})$ lacks xylan hydrolytic enzymes (endoxylanases and $\beta$-xylosidases; Subramaniyan and Prema, 2002). To obtain a xylanolytic E. coli, Salamanca-Cardona et al. (2014a) expressed an endoxylanase (XylB) and a $\beta$-xylosidase (XynB) in E. coli LS5218 engineered for $\mathrm{P}(\mathrm{LA}-\mathrm{co}-3 \mathrm{HB})$ production. The resultant strain produced $3.7 \mathrm{~g} / \mathrm{L}$ $\mathrm{P}(\mathrm{LA}-\mathrm{co}-3 \mathrm{HB})$ from a media containing xylan supplemented with xylose, hence the first consolidated bioprocess (CBP) for P(LAco-3 HB) production from xylan. However, this CBP attained low $(<4 \mathrm{~mol} \%)$ LA units in $\mathrm{P}(\mathrm{LA}-\mathrm{co}-3 \mathrm{HB})$. To increase the LA ratio in this system, $\triangle p f l A$ mutation was introduced in xylanolytic E. coli LS5218 expressing $\mathrm{P}(\mathrm{LA}-\mathrm{co}-3 \mathrm{HB})$ biosynthesis enzymes and the cells cultivated on a media containing beechwood xylan (Salamanca-Cardona et al., 2014b). The inactivation of $p f l A$ resulted in the production of $\mathrm{P}(\mathrm{LA}-\mathrm{co}-3 \mathrm{HB})$ with enhanced LA fraction (up to $18.5 \mathrm{~mol} \%$ ) in the copolymer from xylan or xylan supplemented with xylose, underscoring the essentiality of high LA production on the LA incorporation into $\mathrm{P}(\mathrm{LA}-\mathrm{co}-3 \mathrm{HB})$.

The CBP by Salamanca-Cardona et al. (2014a) was a quasi$\mathrm{CBP}$ that required xylose supplementation, and for a strict CBP system to be established, Salamanca-Cardona et al. (2016) established a xylanolytic plasmid system in E. coli JW0885 ( $\triangle p f l A)$ expressing $\mathrm{P}(\mathrm{LA}-c o-3 \mathrm{HB})$ biosynthesis enzymes. The xylanolytic E. coli JW0885 produced P(LA-co-3HB) containing 19.2 mol\% LA. This system can, however, be optimized to establish a strict CBP system that could be used for P(LA-co-3HB) production from xylan, potentially contributing to the reduction of the cost of producing $\mathrm{P}(\mathrm{LA}-\mathrm{co}-3 \mathrm{HB})$.

\section{PROPERTIES OF LA-BASED POLYMERS}

\section{Enantiomeric Purity of LA-Based Polymers}

Enantiopurity of polymers is a significant factor that affects thermal properties of PLA (Worch et al., 2019). Commercial PLA is made either from $\mathrm{L}^{-}$or $\mathrm{D}-\mathrm{LA}$, resulting in $\mathrm{P}[(S)$ LA] (PLLA) and P $[(R)-\mathrm{LA}]$ (PDLA) homopolymers, which are highly crystalline (Masutani and Kimura, 2014). Crystalline homopolymers have high stability near their melting points $\left(T_{\mathrm{m}}\right)$. L-Lactide generates a semicrystalline PLA with a melting transition of around $180^{\circ} \mathrm{C}$ and glass transition temperature $\left(T_{\mathrm{g}}\right)$ of approximately $67^{\circ} \mathrm{C}$, whereas an amorphous stereocomplex of 1:1 L- or D-lactides has a $T_{\mathrm{g}}$ near room temperature and a $T_{\mathrm{m}}$ of $220-230^{\circ} \mathrm{C}$. Enantiopurity thus affects polymer properties. P(LA$c o-3 \mathrm{HB}$ ) was found to have $(R)$-LA and $(R)-3 \mathrm{HB}$ (Taguchi et al., 2008), which could be attributed to the enantiospecificity of PHA synthases, i.e., are specific to $R$-form monomers (Muhammadi et al., 2015) that were inherited by LPE. With chemical synthesis of $\mathrm{P}$ (LA-co-3HB) not attaining $100 \%$, i.e., the biosynthetic system enables the synthesis of optically pure [P(LA-co-3HB)].

\section{Sequential Structure and Molecular Weight of LA-Based Polymers}

Polymer structure, especially monomer sequence, affects the properties of a polymer (Wolf et al., 2009; Lutz et al., 2013; Matsumoto et al., 2018a). High-resolution NMR is an effective method for determining structural and monomer sequence of copolymers (Kricheldorf, 2001). Sequence information could be obtained by ${ }^{1} \mathrm{H}$ NMR. Analysis of $\mathrm{P}(\mathrm{LA}-\mathrm{co}-3 \mathrm{HB})$ detected LA-LA-LA, LA-LA-3HB, 3HB-LA-LA, and 3HB-LA-3HB triads, whereas ${ }^{1} \mathrm{H}-{ }^{13} \mathrm{C}$ COSY-NMR profiles detected LA-LA-LA triads and LA-LA dyads. This revealed sequential polymerization of LA units by LPE. All the triad sequences were detected in P(LAco-3HB) that suggested random distribution of LA and $3 \mathrm{HB}$ monomer units in the copolymer (Yamada et al., 2009). Molecular weight of a polymer affects its tensile strength (Kricheldorf, 2001). In analysis of $\mathrm{P}(\mathrm{LA}-\mathrm{co}-3 \mathrm{HB})$ polymers, it was found that molecular weight $\left(\mathrm{M}_{\mathrm{W}}\right)$ of $\mathrm{P}(\mathrm{LA}-\mathrm{co}-3 \mathrm{HB})$ was dependent on the $\mathrm{LA} / 3 \mathrm{HB}$ ratios; i.e., there was an inverse relationship between LA fraction and $\mathrm{M}_{\mathrm{W}}$ (Shozui et al., 2010b; Yamada et al., 2011; Song et al., 2012; Salamanca-Cardona et al., 2017; Nduko and Taguchi, 2019). This relationship was also maintained with the thermal properties ( $\mathrm{Tg}$ and $\mathrm{Tc}$ ) of the copolymers.

\section{Thermal and Mechanical Properties of LA-Based Polymers}

The thermal properties of PHAs determine their ideal processing and utilization temperatures and affect polymer quality in terms of parameters such as crystallization and heat resistance. PLA homopolymer is either amorphous or semicrystalline (40-60\% crystallinity; Mehta et al., 2005). For amorphous PLA, its $T_{\mathrm{g}}$ is the determinant of its upper use temperature, whereas in semicrystalline PLAs, both $T_{\mathrm{g}}$ (approximately $58^{\circ} \mathrm{C}$ ) and $T_{\mathrm{m}}$ $\left(130-230^{\circ} \mathrm{C}\right)$ determines the use temperatures of the polymer. The $T_{\mathrm{g}}$ and $T_{\mathrm{m}}$ are both dependent on the molecular weight, 

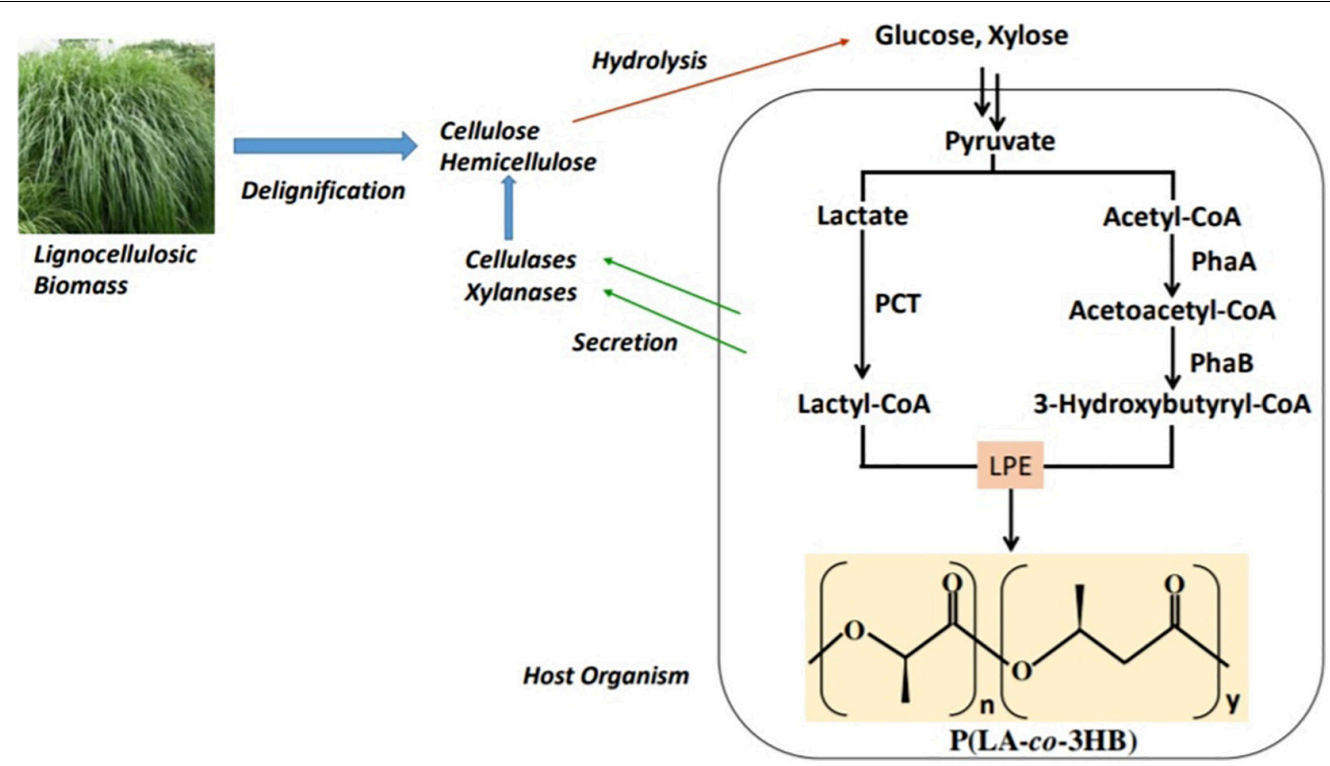

FIGURE 5 | A consolidated bioprocess where the host is engineered to combine cellulose and/or hemicellulose hydrolysis and P(LA-CO-3HB) production. PCT, propionyl-CoA trabnsferase; PhaA, $\beta$-ketothiolase; PhaB, NADPH-dependent acetoacetyl-CoA reductase; and LPE, lactate (LA)-polymerizing enzyme.

thermal history, optical composition, and the primary structure of the polymer. $\mathrm{PHB}$ is semicrystalline with a $T_{\mathrm{m}}$ of $174-179^{\circ} \mathrm{C}$ and $T_{\mathrm{g}}$ of $-7^{\circ} \mathrm{C}$ (Anjum et al., 2016). PLA is a transparent polymer whereas $\mathrm{P}(3 \mathrm{HB})$ is an opaque polymer, which is consistent with their $T_{\mathrm{g}}$ (Nduko et al., 2015). Microbial P(LAco-3HB) exhibited intermediate $\operatorname{Tg}\left(-6\right.$ to $\left.34^{\circ} \mathrm{C}\right)$, which varied with the LA/3HB ratio (Yamada et al., 2011). The $T_{\mathrm{m}}$ and melting enthalpy $\left(\Delta H_{\mathrm{m}}\right)$ of $\mathrm{P}(\mathrm{LA}-\mathrm{co}-3 \mathrm{HB})$ with $29-47 \mathrm{~mol} \%$ LA were lower than those of $\mathrm{P}(3 \mathrm{HB})$ and PLA homopolymers. The lower $T_{\mathrm{m}}$ and $\Delta H_{\mathrm{m}}$ of $\mathrm{P}(\mathrm{LA}-\mathrm{co}-3 \mathrm{HB})$ could be attributed to low crystallinity due to copolymerization as compared with the respective homopolymers. Copolymerization could allow the customization of thermal properties and widens the narrow processing window of PLA and PHB homopolymers.

Solid materials made from high $\mathrm{M}_{\mathrm{W}}(>100 \mathrm{kDa})$ PLA are strong, whereas those made of PLA of low $\mathrm{M}_{\mathrm{W}}(<70 \mathrm{kDa})$ are weak and ductile (Moon et al., 2001a,b; Cicero et al., 2002; Södergård and Stolt, 2002; Castro-Aguirre et al., 2016). The increase in strength with $M_{w}$ is, however, accompanied with decrease in elongation-at-break (Engelberg and Kohn, 1991). On its part, $\mathrm{P}(3 \mathrm{HB})$ is brittle at low $\mathrm{Mw}$; for instance, a $22-\mathrm{kDa}$ polymer elongates only $2 \%$ at break with a force of $8.5 \mathrm{MPa}$ (Srubar et al., 2012). P(3HB)s strength improves with increase in Mw. For example, at $370 \mathrm{kDa}$, strength is $36 \mathrm{MPa}$, with some alterations in strain behavior (Engelberg and Kohn, 1991; Cox, 1994), whereas at $11 \mathrm{MDa}, \mathrm{P}(3 \mathrm{HB})$ 's strength is $62 \mathrm{MPa}$, and elongation-at-break is 58\% (Kusaka et al., 1999). Assessment of microbial $\mathrm{P}(\mathrm{LA}-\mathrm{co}-3 \mathrm{HB})$ found its Young modulus to be inversely related to the LA fraction in the copolymer and ranged between 148 and $905 \mathrm{MPa}$, which was lower than that of PLA $(1,020 \mathrm{MPa})$, and $\mathrm{P}(3 \mathrm{HB} ; 1,079 \mathrm{MPa})$ homopolymers (Yamada et al., 2011). P(LA-co-3HB) were more flexible compared with PLA and $\mathrm{P}(3 \mathrm{HB})$ homopolymers. For instance, the elongation at break of the $\mathrm{P}(29$ mol\% LA-co-3HB) was $156 \%$ (Yamada et al., 2011). This indicated that $\mathrm{P}(\mathrm{LA}-\mathrm{co}-3 \mathrm{HB})$ is more elastic than PLA and $\mathrm{P}(3 \mathrm{HB})$ homopolymers; hence, the alteration of LA fractions in $\mathrm{P}(\mathrm{LA}-\mathrm{co}-3 \mathrm{HB})$ could lead to the formation of materials with desired mechanical properties.

\section{MICROBIAL DEGRADATION OF $P(L A-C O-3 H B)$}

Polyhydroxyalkanoates, in particular $\mathrm{P}(\mathrm{LA}-\mathrm{co}-3 \mathrm{HB})$, are promising materials with potential practical applications. With perceived increase in their production, efforts should be made to study $\mathrm{P}(\mathrm{LA}-\mathrm{co}-3 \mathrm{HB})$ degradation in the environment. PHA degradation generates products $\left(\mathrm{CO}_{2}, \mathrm{H}_{2} \mathrm{O}\right.$, methane, and LA) that are safe to the environment (Volova et al., 2017). In nature, $\mathrm{P}(3 \mathrm{HB})$ is degraded by microbes expressing extracellular PHA-depolymerases, whereas PDLA is not easily biodegraded (Kawai et al., 2011). The biodegradation of $\mathrm{P}(\mathrm{LA}-\mathrm{co}-3 \mathrm{HB})$ will be dependent on the degradability LA and $3 \mathrm{HB}$ components in the copolymer. Sun et al. (2014), screened soil samples from Sapporo, Japan, for microorganisms degrading $\mathrm{P}(\mathrm{LA}-\mathrm{co}-3 \mathrm{HB})$. They used $\mathrm{P}(67 \mathrm{~mol} \% \mathrm{LA}-\mathrm{co}-3 \mathrm{HB})$ as the substrate and isolated a microorganism identified as Variovorax spp. C34 that had high $\mathrm{P}(\mathrm{LA}-\mathrm{co}-3 \mathrm{HB})$ and $\mathrm{P}(3 \mathrm{HB})$ degradation ability but was not degrading PDLA. Phylogenetic analysis using 16S rRNA gene sequencing found Variovorax spp. to be close to the members of the Comamonadaceae family such as Acidovorax sp. TP4 (Jendrossek et al., 1993), Comamonas sp. (Kasuya et al., 1994), Comamonas testosteroni (Kusaka et al., 1999), and Delftia acidovorans (Kasuya et al., 1997) that secrete extracellular $\mathrm{P}(3 \mathrm{HB})$ depolymerases. In the supernatant of the Variovorax spp. C34 culture, $\mathrm{P}(\mathrm{LA}-\mathrm{co}-3 \mathrm{HB})$ degradation was detected, indicating 
that the organism produced an extracellular depolymerase(s). The $\mathrm{P}(\mathrm{LA}-\mathrm{co}-3 \mathrm{HB})$ depolymerase was purified and found to degrade $\mathrm{P}(\mathrm{LA}-\mathrm{co}-3 \mathrm{HB})$ and $\mathrm{P}(3 \mathrm{HB})$, but not PLLA or PDLA (Sun et al., 2014). The degradation of $\mathrm{P}(\mathrm{LA}-\mathrm{co}-3 \mathrm{HB})$ was faster than the degradation of $\mathrm{P}(3 \mathrm{HB})$, and this could be attributed the lower crystallinity in $\mathrm{P}(\mathrm{LA}-\mathrm{co}-3 \mathrm{HB})$ compared with the higher crystallinity of $\mathrm{P}(3 \mathrm{HB})$.

In another study, Hori et al. (2020) screened for bacterial groups degrading $\mathrm{P}(\mathrm{D}-\mathrm{LA}-\mathrm{co}-3 \mathrm{HB})$ from soil. Specific emphasis was on the degradation of D-LA clustering units in the copolymer using chemically synthesized D-LA homo-oligomers. Based on clear zone formation on agar plates containing P(64 mol\% DLA-co-3HB) and 16S rRNA sequence analysis, eight Variovorax, three Acidovorax, and one Burkholderia strains were isolated and these strains were closely related to previously identified PHA-degrading bacteria (Sun et al., 2014). The isolated strains were found to consume $\mathrm{P}(\mathrm{D}-\mathrm{LA}-\mathrm{co}-3 \mathrm{HB})$ in a liquid culture, although a D-LA fraction remained unconsumed, and this was attributed to a D-LA clustering structure in the copolymer. When the isolated strains were cultivated with the D-LA homooligomers, it was found that degradation was dependent on the degree of polymerization (DP). For instance, six Variovorax and one Acidovorax strains partly consumed oligomers with 10-30 DP. On the other hand, oligomers with DP of 2060 were not consumed by the isolates, indicating DP as the degradation determining factor. With molecular dynamic simulation, it was proposed that the upper cutoff DP for D-LA homo-oligomer degradation could be determined by conformational structure of the oligomers in water, and this is particularly important in molecular design of biodegradable D-LA-containing polymers.

\section{PRODUCTION OF LA OLIGOMERS}

Since Taguchi et al. (2008) reported for the first time the microbial factory for the synthesis of $\mathrm{P}(\mathrm{LA}-\mathrm{co}-3 \mathrm{HB})$, a number of attempts have been made to enhance the LA fraction in the polymer (Yamada et al., 2009, 2011; Song et al., 2012; Nduko et al., 2013a, 2014). In these studies, an unusual phenomenon regarding the molecular weights of the polymers has been observed. The molecular weights $\left(\mathrm{M}_{\mathrm{n}}\right.$ and $\left.\mathrm{M}_{\mathrm{W}}\right)$ of PLA-like polymers and PLA were lower (magnitude of $10^{3}$ ) than those of $\mathrm{P}(\mathrm{LA}-\mathrm{co}-3 \mathrm{HB})$ with $<70$ mol\% LA fraction $\left(10^{4}-10^{5}\right.$; Shozui et al., 2011; Song et al., 2012; Nduko and Taguchi, 2019). The low molecular weights with high LA fractions in $\mathrm{P}(\mathrm{LA}-\mathrm{co}-3 \mathrm{HB})$ suggested the possible production of LA oligomers by the recombinant microorganisms. These oligomers, if produced, can be purified and chemically catalyzed in a short-cut process to generate PLA.

The possibility of LA oligomer production in the $\mathrm{P}(\mathrm{LA}-\mathrm{co}$ $3 \mathrm{HB})$ biosynthesis system was explored by Utsunomia et al. (2017c) as earlier discussed by Nduko and Taguchi (2019). E. coli expressing LPE, PCT, PhaA, and PhaB (Taguchi et al., 2008) was cultivated on glucose and the supernatant examined by NMR (Figure 6). The chemical shifts ( $\delta$ in $\mathrm{ppm}$ ) in ${ }^{1} \mathrm{H}$ NMR of the extracted fraction of the supernatant were similar to those of $\mathrm{P}(\mathrm{LA}-\mathrm{co}-3 \mathrm{HB})$, indicating the presence of LA oligomers in the supernatant. The slight differences between supernatant extract and $\mathrm{P}(\mathrm{LA}-\mathrm{co}-3 \mathrm{HB})$ polymer was linked to the molecular weight differences between the polymers and oligomers (Yamada et al., 2009; Nduko et al., 2012a; Utsunomia et al., 2017c). Based on ${ }^{1} \mathrm{H}$ NMR, the oligomers in the supernatant had $63 \mathrm{~mol} \%$ LA fraction (Utsunomia et al., 2017c). The electrospray ionization time-of-flight mass spectrometry (ESI-TOF-MS) examination of the extract found a bimodal distribution of the oligomers with periodic $\mathrm{m} / \mathrm{z}$ values of between 400 and 1,400, which indicated that the oligomers were between $\sim 4$ - and 19-mer comprising both LA and $3 \mathrm{HB}$ units. The peak tops of the bimodal distribution were 7 - and 12-mer, for LA and 3HB, respectively.

The researchers sought to enhance LA oligomer secretion from $\mathrm{P}(\mathrm{LA}-$ co-3HB) polymer-producing $E$. coli by the inclusion of chain transfer (CT) agents in the culture media. In the presence of CT agents, PHA synthase will lose polymerization activity and instead transfer polymer chain to a CT agent containing a hydroxyl group (Madden et al., 1999; Miyahara et al., 2019). This will lead to synthesis of polymers with low molecular weight and enhance the production of oligomers (Hiroe et al., 2013). Some of the CT agents that have been demonstrated to reduce molecular weight of PHAs include polyethylene glycols and short-chain alcohols (Shi et al., 1996; Ashby et al., 1997; Tomizawa et al., 2010; Hiroe et al., 2013; Thomson et al., 2014). Utsunomia et al. (2017c) evaluated four CT agents for their effectiveness in enhancing LA oligomer secretion. It was found that diethylene glycol (DEG) was the most effective in enhancing LA oligomer production, concomitantly reducing molecular weight of P(LAco-3HB) in the cells.

The enhanced LA oligomer secretion into the medium with the addition of DEG was not as a result of cell lysis (Utsunomia et al., 2017c). With 5\% DEG addition into the medium, LA oligomer yield of $8.3 \pm 1.5 \mathrm{~g} \mathrm{~L}^{-1}$ was obtained with LA fraction of $86.0 \pm 4.5 \mathrm{~mol} \%$. Upon extraction from the supernatant, $3.2 \mathrm{~g} \mathrm{~L}^{-1}$ of the LA oligomers was recovered and was free of DEG, although ${ }^{1} \mathrm{H}-{ }^{1} \mathrm{H}$ COSY-NMR indicated that LA oligomers were covalently capped with DEG at their carboxy terminal (Utsunomia et al., 2017c). Similarly, ${ }^{1} \mathrm{H}^{-1} \mathrm{H}$ COSY-NMR and ${ }^{1} \mathrm{H}-{ }^{1} \mathrm{H}$ DOSY NMR revealed that the high-molecular-weight $\mathrm{P}(\mathrm{LA}-\mathrm{co}-3 \mathrm{HB})$ accumulated in the cells was also terminated with DEG at the carboxyl terminal. The ESI-TOF-MS analysis of LA oligomers produced with addition of DEG detected periodic $\mathrm{m} / \mathrm{z}$ values in the range $400-800$ that corresponds to $\sim 4$ - to 10 -mers, suggesting shorter oligomers were generated with addition of DEG compared with those without (Utsunomia et al., 2017c).

Evaluation of LA concentration found that intracellular LA oligomer $(1.8 \mathrm{~g} / \mathrm{L})$ in E. coli cells was higher than extracellular concentration $(0.4 \mathrm{~g} / \mathrm{L})$, pointing out to the presence of a secretion barrier (Utsunomia et al., 2017c). To pinpoint the secretion route in $E$. coli for LA oligomers, a loss-of-function screening strategy was adopted. This involved screening of 209 deletants of membrane proteins known to transport organic compounds (Utsunomia et al., 2017a). Cultivation of the deletants found that 55 of them had reduced extracellular LA oligomer concentration compared with the parental strain. There was interest in mutants with elevated intracellular LA oligomers as this could indicate disruption of LA secretion 


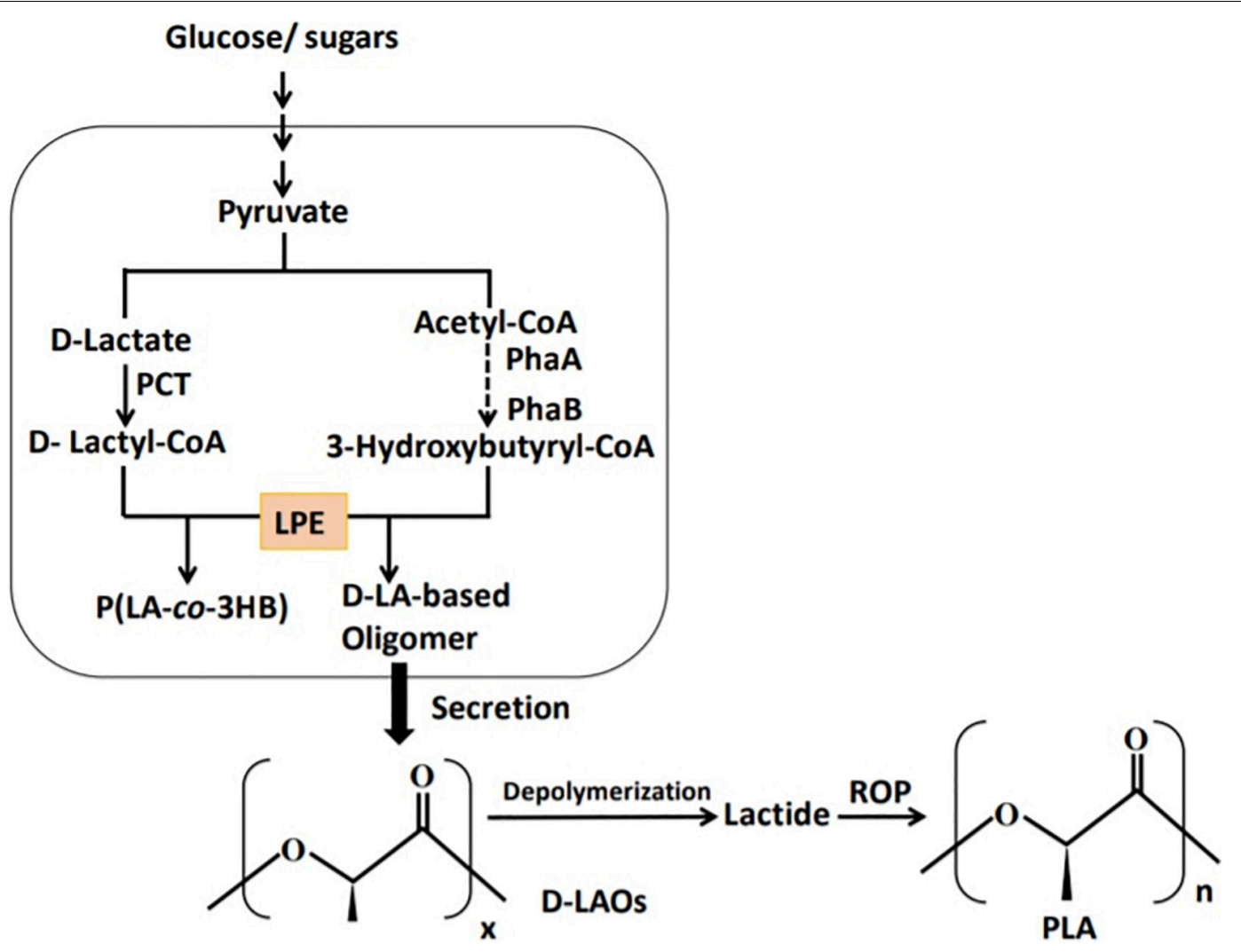

FIGURE 6 | Schematic presentation of the P(LA-Co-3HB) production system adapted for the production of D-LA-based oligomers. PCT, propionyl-CoA trabnsferase; PhaA, $\beta$-ketothiolase; PhaB, NADPH-dependent acetoacetyl-CoA reductase; and LPE, lactate (LA)-polymerizing enzyme.

mechanism. Consequently, seven mutants $(\triangle m p F, \Delta \arg T$, $\Delta m n g A, \Delta m a c A, \Delta o m p G, \Delta c i t A$, and $\Delta c p x A)$ exhibiting either decreased or increased LA oligomer secretion were cultivated without plasmids and were found to grow normally. This suggested that the membrane proteins that were deleted were not injurious to cell growth. On the basis of these results, it was proposed that secretion of LA oligomers through the outer membrane was mediated by passive diffusion via porins including OmpG and OmpF. To pass through the inner membrane, inner membrane-associated proteins such as ArgT, CitA, CpxA, and MacA were proposed to be transporting LA oligomers (Utsunomia et al., 2017a).

To demonstrate the applicability of the LA oligomers for PLA synthesis, lactide was synthesized from LA oligomers $(68 \mathrm{~mol} \%$ LA, 3- to 7-mers) produced by E. coli growing on glucose with 5\% DEG (Utsunomia et al., 2017b). Alongside this, LA oligomers with 61 mol\% LA with 3- to 16-mers synthesized by $E$. coli cultivated on glucose supplemented with L-LA homo oligomers (100 mol\% LA) and mers ranging from 3 to 14 were used as a control. In either case, zinc oxide was used as a catalyst to generate the lactides. Although D-LA oligomers could form lactides, their conversion rates (25\% for D-LA oligomer and $13 \%$ for D-LA oligomer-DEG) were lower when compared to $77 \%$ obtained with the control (L-LA oligomers; Utsunomia et al., 2017b). The lower conversion rate of D-LA oligomers was attributed to the presence of $3 \mathrm{HB}$ units that could hinder lactide conversion rates. As a result, enhancing the LA fraction in the D-LA oligomers might increase the conversion rate. In subsequent experiments, xylose was used to produce LA oligomers having $97 \mathrm{~mol} \%$ LA. On extraction from the supernatant, LA oligomers containing 89 mol\% LA were obtained, and when used for lactide synthesis, the conversion rate was improved (Utsunomia et al., 2017b). This indicated that use of LA oligomers with high LA fraction is essential for improved lactide conversion. In addition, molecular weight of the oligomers could affect lactide yield as short oligomers vaporize and get lost during heating. Therefore, production of longer oligomers is a potent research area to increase lactide synthesis.

\section{CONCLUSION AND FUTURE OUTLOOK}

Polylactic acid and PHAs have attracted much attention in recent decades in research as well in industry. These materials have versatile properties; however, the major drawback of these polymers is their production cost. For the production of highmolecular-weight PLA, ROP has found industrial use. Coupling ROP with advances in fermentative production of LA has reduced PLA production cost. Despite the advances in ROP chemistry and life-cycle assessments of PLA production compared to equivalent 
fossil fuel-derived plastics being positive, the multistep chemo-bio process for PLA production is still considered to be complex and expensive (Matsumoto and Taguchi, 2010; Lasprilla et al., 2012; Vink and Davies, 2015; De Clercq et al., 2018). Lactide formation from LA production involves many purification steps (De Clercq et al., 2018), which contribute approximately $30 \%$ of the cost of PLA, hampering its competitiveness against fossil fuel-derived plastics (Corma et al., 2007; Van Wouwe et al., 2016).

Consequently, researchers have undertaken crucial steps to improve PLA synthesis and make it more feasible. One such strategy is the establishment of a single-pot bioprocess for PLA synthesis analogous to the synthesis of PHAs. This was, however, achieved in 2008 (Taguchi et al., 2008), where a PHA synthase was engineered to acquire LApolymerizing activity. The engineered PHA synthase termed LPE was coupled with LA-CoA supplying enzyme (PCT) and 3HB monomer supplying enzymes to establish a whole-cell bioprocess for the production of LA-based polymers, $\mathrm{P}(\mathrm{LA}-$ co-3HB). Analysis of the $\mathrm{P}(\mathrm{LA}-\mathrm{co}-3 \mathrm{HB})$ found that material properties varied with the LA fraction in the copolymer. As the pioneering study for $\mathrm{P}(\mathrm{LA}-\mathrm{co}-3 \mathrm{HB})$ achieved only low LA fractions in the copolymer, enzyme evolutionary engineering, metabolic engineering, host change, disruption of $\sigma$ factors, and fermentation manipulation techniques (Table 1) were recruited to improve the LA fractions in $\mathrm{P}(\mathrm{LA}-\mathrm{co}-3 \mathrm{HB})$ and eventual production of PLA in microorganisms. The PLA synthesized by microorganisms had similar properties to the chemically synthesized PLA.

The price of the substrate used as the carbon source for PLA and P(LA-co-3HB), polymer yield on the carbon source, and downstream processes determines the ultimate cost of the polymers. Lignocellulosic biomass is abundant in nature and offers an inexpensive carbon source for the production of PLA and LA-based polymers. As has been demonstrated, glucose and xylose, the major components of cellulose and hemicellulose, respectively, are good substrates for the production of LA-based polymers with high LA fractions. Furthermore, lignocellulose biomass hydrolyzates and xylan have been shown as substrates for production of LA-based polymers. If more effort is directed toward optimizing the processes and utilizing all biomass components, then the cost of producing LA-based polymers and PLA will reduce and make the polymers competitive.

The microbial synthesis of high LA P(LA-co-3HB) and PLA suffered in terms of polymer yields and molecular weight. At LA fractions in $\mathrm{P}(\mathrm{LA}-\mathrm{co}-3 \mathrm{HB})$ greater than $70 \mathrm{~mol} \%$ and in PLA biosynthesis, only small amounts of polymer are synthesized, and the polymers are of low molecular weight (Matsumoto et al., 2018b). It was hypothesized that rather than substrate specificity of LPE, polymer size limitation was due to the molecular dynamics of PDLA. Molecular dynamics of the polymer could be affected by the $\mathrm{Tg}$ of the synthesized polymer. High-molecular-weight PLA has a $T_{\mathrm{g}}$ of approximately $60^{\circ} \mathrm{C}$, which reduces with decrease in $\mathrm{M}_{\mathrm{W}}$. As cultivation temperatures for polymer production was $30^{\circ} \mathrm{C}$, the $T_{\mathrm{g}}$ of low $\mathrm{M}_{\mathrm{w}}$ PLA like polymers and PLA could have fallen below this, gradually stalling polymer synthesis. Thus, efforts to overcome this stalling mechanism need to be undertaken to improve polymer yield and molecular weight. During degradation experiments of $\mathrm{P}(\mathrm{LA}-\mathrm{co}-3 \mathrm{HB})$ and $\mathrm{D}-\mathrm{LA}$ oligomers, it was found that the DP affected degradation of D-LA oligomer, whereby long D-LA oligomers are not degraded. Therefore, efforts are needed on the molecular design of biodegradable D-LA-containing polymers.

The $\mathrm{P}(\mathrm{LA}-\mathrm{co}-3 \mathrm{HB})$ biosynthesis system was found to secrete LA oligomers that were converted into lactides, antecedents for chemical PLA production. Endeavors have been made to unravel LA-oligomer secretion mechanism. However, examinations to pinpoint the precise mechanism to better understand candidate transporters are vital as this will direct targeted plans to advance LA oligomer secretion. Despite the fact that the produced oligomers were forming lactides mediated by a catalyst, the conversion rate was low, a phenomenon attributed to the presence of $3 \mathrm{HB}$ units in the chain. Therefore, efforts should be directed toward the PLA synthesis system to generate LA oligomers that could be coupled with the chemical step for the synthesis of high-molecular-weight PLA. In addition, improving the oligomer yields is another research frontier. Strategies to increase the yield of PLA, P(LA-co-3HB), and LA oligomers along with the utilization of lignocellulosic biomass and other agroindustrial byproducts have potential of creating a sustainable biorefinery for the production of LA-based materials.

The systems discussed herein have scale-up potential and could improve the competitiveness of LA-based polymers and materials against the petrochemical-derived counterparts. Along with exploration of substrates for production, polymer yields, monomer composition and sequence, and oligomer production, the scale-up potential should be evaluated. As $\mathrm{P}(\mathrm{LA}-\mathrm{co}-3 \mathrm{HB})$ are biodegradable, they could emerge as ecofriendly alternatives to the petrochemical-based plastics.

\section{AUTHOR CONTRIBUTIONS}

ST conceived and presented the idea. JN wrote the manuscript with the support of ST. ST and JN discussed and contributed to the final version of the manuscript. Both authors contributed to the article and approved the submitted version.

\section{ACKNOWLEDGMENTS}

The works introduced in this review have been financially supported in part by the Japan Science and Technology Agency (JST), A-Step program (JPMJTM19YC to ST), and New Energy and Industrial Technology Development Organization (NEDO), International Collaborative Program on Innovative Technology in Clean Energy Field [P20005 (0804001) to ST]. 


\section{REFERENCES}

Al-Battashi, H. S., Annamalai, N., Sivakumar, N., Al-Bahry, S., Tripathi, B. N., Nguyen, Q. D., et al. (2019). Lignocellulosic biomass (LCB): a potential alternative biorefinery feedstock for polyhydroxyalkanoates production. Rev. Environ. Sci. Biotechnol. 18, 183-205. doi: 10.1007/s11157-018-09 488-4

Albuquerque, P., and Malafaia, C. B. (2018). Perspectives on the production, structural characteristics and potential applications of bioplastics derived from polyhydroxyalkanoates. Int. J. Biol. Macromol. 107(Pt A), 615-625. doi: 10. 1016/j.ijbiomac.2017.09.026

Alcântara, J. M. C., Distante, F., Storti, G., Moscatelli, D., Morbidelli, M., and Sponchioni, M. (2020). Current trends in the production of biodegradable bioplastics: the case of polyhydroxyalkanoates. Biotechnol. Adv. 42:107582. doi: 10.1016/j.biotechadv.2020.107582

Anjum, A., Zuber, M., Zia, K. M., Noreen, A., Anjum, M. N., and Tabasum, S. (2016). Microbial production of polyhydroxyalkanoates (PHAs) and its copolymers: a review of recent advancements. Int. J. Biol. Macromol. 89, 161-174. doi: 10.1016/j.ijbiomac.2016.04.069

Ashby, R. D., Shi, F., and Gross, R. A. (1997). Use of poly(ethylene glycol) to control the end group structure and molecular weight of poly(3-hydroxybutyrate) formed by Alcaligenes latus DSM 1122. Tetrahedron 53, 15209-15223. doi: 10.1016/s0040-4020(97)00958-7

Auras, R., Harte, B., and Selke, S. (2004). An overview of polylactides as packaging materials. Macromol. Biosci. 4, 835-864. doi: 10.1002/mabi.200400043

Bhatia, S. K., Gurav, R., Choi, T. R., Jung, H. R., Yang, S. Y., Moon, Y. M., et al. (2019). Bioconversion of plant biomass hydrolysate into bioplastic (polyhydroxyalkanoates) using Ralstonia eutropha 5119. Bioresour. Technol. 271, 306-315. doi: 10.1016/j.biortech.2018.09.122

Brethauer, S., and Studer, M. H. (2015). Biochemical conversion processes of lignocellulosic biomass to fuels and chemicals - a review. Chimia 69, 572-581. doi: 10.2533/chimia.2015.572

Carpine, R., Olivieri, G., Hellingwerf, K. J., Pollio, A., and Marzocchella, A. (2020). Industrial production of poly- $\beta$-hydroxybutyrate from $\mathrm{CO} 2$ : can cyanobacteria meet this challenge? Processes 8:323. doi: 10.3390/pr8030323

Castro-Aguirre, E., Iñiguez-Franco, F., Samsudin, H., Fang, X., and Auras, R. (2016). Poly(lactic acid)-mass production, processing, industrial applications, and end of life. Adv. Drug Deliv. Rev. 107, 333-366. doi: 10.1016/j.addr.2016. 03.010

Chek, M. F., Hiroe, A., Hakoshima, T., Sudesh, K., and Taguchi, S. (2019). PHA synthase $(\mathrm{PhaC})$ : interpreting the functions of bioplastic-producing enzyme from a structural perspective. Appl. Microbiol. Biotechnol. 103, 1131-1141. doi: 10.1007/s00253-018-9538-8

Choi, S. Y., Chae, T. U., Shin, J., Im, J. A., and Lee, S. Y. (2020). Biosynthesis and characterization of poly(d-lactate-co-glycolate-co-4-hydroxybutyrate). Biotechnol. Bioeng. 117, 2187-2197. doi: 10.1002/bit.27354

Choi, S. Y., Cho, I. J., Lee, Y., Park, S., and Lee, S. Y. (2019). Biocatalytic synthesis of polylactate and its copolymers by engineered microorganisms. Methods Enzymol. 627, 125-162. doi: 10.1016/bs.mie.2019.04.032

Choi, S. Y., Park, S. J., Kim, W. J., Yang, J. E., Lee, H., Shin, J., et al. (2016). One-step fermentative production of poly(lactate-co-glycolate) from carbohydrates in Escherichia coli. Nat. Biotechnol. 34, 435-440. doi: 10.1038/nbt. 3485

Cicero, J. A., Dorgan, J. R., Janzen, J., Garrett, J., Runt, J., and Lin, J. S. (2002). Supramolecular morphology of two-step, melt-spun poly(lactic acid) fibers. J. Appl. Polym. Sci. 86, 2828-2838. doi: 10.1002/app.11267

Corma, A., Iborra, S., and Velty, A. (2007). Chemical routes for the transformation of biomass into chemicals. Chem. Rev. 107, 2411-2502. doi: 10.1021/cr050989d

Cox, M. K. (1994). "Biodegradable plastics and polymers," in Proceedings of the Third International Science Workshop Biodegradable Plastics Polymer, eds Y. Doi and K. Fukuda (Osaka: Elsevier), 120-134.

De Clercq, R., Dusselier, M., Makshina, E., and Sels, B. F. (2018). Catalytic gasphase production of lactide from renewable alkyl lactates. Angewandte Chemie 57, 3074-3078. doi: 10.1002/anie.201711446

de Paula, R. G., Antoniêto, A., Ribeiro, L., Srivastava, N., O’Donovan, A., Mishra, P. K., et al. (2019). Engineered microbial host selection for value-added bioproducts from lignocellulose. Biotechnol. Adv. 37:107347. doi: 10.1016/j. biotechadv.2019.02.003
Elmowafy, E., Abdal-Hay, A., Skouras, A., Tiboni, M., Casettari, L., and Guarino, V. (2019). Polyhydroxyalkanoate (PHA): applications in drug delivery and tissue engineering. Expert Rev. Med. Devices 16, 467-482. doi: 10.1080/17434440. 2019.1615439

Engelberg, I., and Kohn, J. (1991). Physico-mechanical properties of degradable polymers used in medical applications: a comparative study. Biomaterials 12, 292-304. doi: 10.1016/0142-9612(91)90037-b

Gadgil, B. S. T., Killi, N., and Rathna, G. (2017). Polyhydroxyalkanoates as biomaterials. Med. Chem. Commu. 8, 1774-1787.

Gopi, S., Kontopoulou, M., Ramsay, B. A., and Ramsay, J. A. (2018). Manipulating the structure of medium-chain-length polyhydroxyalkanoate (MCL-PHA) to enhance thermal properties and crystallization kinetics. Int. J. Biol. Macromol. 119, 1248-1255. doi: 10.1016/j.ijbiomac.2018.08.016

Goto, S., Hokamura, A., Shiratsuchi, H., Taguchi, S., Matsumoto, K., Abe, H., et al. (2019a). Biosynthesis of novel lactate-based polymers containing mediumchain-length 3-hydroxyalkanoates by recombinant Escherichia coli strains from glucose. J. Biosci. Bioeng. 128, 191-197. doi: 10.1016/j.jbiosc.2019.01.009

Goto, S., Suzuki, N., Matsumoto, K., Taguchi, S., Tanaka, K., and Matsusaki, H. (2019b). Enhancement of lactate fraction in poly(lactate-co-3-hydroxybutyrate) synthesized by Escherichia coli harboring the D-lactate dehydrogenase gene from Lactobacillus acetotolerans HT. J. Gen. Appl. Microbiol. 65, 204-208. doi: 10.2323/jgam.2018.09.002

Grage, K., McDermott, P., and Rehm, B. (2017). Engineering Bacillus megaterium for production of functional intracellular materials. Microb. Cell Fact. 16:211.

Grigore, M. E., Grigorescu, R. M., Iancu, L., Ion, R. M., Zaharia, C., and Andrei, E. R. (2019). Methods of synthesis, properties and biomedical applications of polyhydroxyalkanoates: a review. J. Biomater. Sci. Polym. Ed. 30, 695-712. doi: 10.1080/09205063.2019.1605866

Hiroe, A., Hyakutake, M., Thomson, N. M., Sivaniah, E., and Tsuge, T. (2013). Endogenous ethanol affects biopolyester molecular weight in recombinant Escherichia coli. ACS Chem. Biol. 8, 2568-2576. doi: 10.1021/cb400465p

Hori, C., Sugiyama, T., Watanabe, K., Sun, J., Kamada, Y., Ooi, T., et al. (2020). Isolation of poly[d-lactate (LA)-co-3-hydroxybutyrate)]-degrading bacteria from soil and characterization of d-LA homo-oligomer degradation by the isolated strains. Polym. Degrad. Stab. 179:109231. doi: 10.1016/j. polymdegradstab.2020.109231

Hori, C., Yamazaki, T., Ribordy, G., Takisawa, K., Matsumoto, K., Ooi, T., et al. (2019). High-cell density culture of poly(lactate-co-3-hydroxybutyrate)producing Escherichia coli by using glucose/xylose-switching fed-batch jar fermentation. J. Biosci. Bioeng. 127, 721-725. doi: 10.1016/j.jbiosc.2018.11.006

Hu, Y., Daoud, W. A., Cheuk, K., and Lin, C. (2016). Newly developed techniques on polycondensation, ring-opening polymerization and polymer modification: focus on poly(lactic acid). Materials 9:133. doi: 10.3390/ma9030133

Jendrossek, D., Knoke, I., Habibian, R. B., Steinbüchel, A., and Schlegel, H. G. (1993). Degradation of poly(3-hydroxybutyrate), PHB, by bacteria and purification of a novel PHB depolymerase from Comamonas sp. J. Environ. Polym. Degr. 1, 53-63. doi: 10.1007/BF01457653

Jo, S. J., Maeda, M., Ooi, T., and Taguchi, S. (2006). Production system for biodegradable polyester polyhydroxybutyrate by Corynebacterium glutamicum. J. Biosci. Bioeng. 102, 233-236. doi: 10.1263/jbb.102.233

Jo, S. J., Matsumoto, K., Leong, C. R., Ooi, T., and Taguchi, S. (2007). Improvement of poly(3-hydroxybutyrate) $[\mathrm{P}(3 \mathrm{HB})]$ production in Corynebacterium glutamicum by codon optimization, point mutation and gene dosage of $\mathrm{P}(3 \mathrm{HB})$ biosynthetic genes. J. Biosci. Bioeng. 104, 457-463. doi: 10.1263/jbb.104.457

Kadoya, R., Kodama, Y., Matsumoto, K., and Taguchi, S. (2015a). Enhanced cellular content and lactate fraction of the poly(lactate-co-3-hydroxybutyrate) polyester produced in recombinant Escherichia coli by the deletion of $\sigma$ factor RpoN. J. Biosci. Bioeng. 119, 427-429. doi: 10.1016/j.jbiosc.2014.09.001

Kadoya, R., Kodama, Y., Matsumoto, K., and Taguchi, S. (2015b). Indirect positive effects of a sigma factor RpoN deletion on the lactate-based polymer production in Escherichia coli. Bioengineered 6, 307-311. doi: 10.1080/21655979.2015. 1069449

Kadoya, R., Matsumoto, K., Ooi, T., and Taguchi, S. (2015c). MtgA deletiontriggered cell enlargement of Escherichia coli for enhanced intracellular polyester accumulation. PLoS One 10:e0125163. doi: 10.1371/journal.pone. 0125163

Kadoya, R., Matsumoto, K., Takisawa, K., Ooi, T., and Taguchi, S. (2018). Enhanced production of lactate-based polyesters in Escherichia coli from a mixture of 
glucose and xylose by Mlc-mediated catabolite derepression. J. Biosci. Bioeng. 125, 365-370. doi: 10.1016/j.jbiosc.2017.11.003

Kasuya, K., Doi, Y., and Yao, T. (1994). Enzymatic degradation of poly((R)3hydroxybutyrate) by Comamonas testosteroni ATSU of soil bacterium. Polym. Degrad. Stab. 45, 379-386. doi: 10.1016/0141-3910(94)90208-9

Kasuya, K., Inoue, Y., Tanaka, T., Akehata, T., Iwata, T., Fukui, T., et al. (1997). Biochemical and molecular characterization of the polyhydroxybutyrate depolymerase of Comamonas acidovorans YM1609, isolated from freshwater. Appl. Environ. Microbiol. 63, 4844-4852. doi: 10.1128/aem.63.12.4844-4852. 1997

Kawai, F., Nakadai, K., Nishioka, E., Nakajima, H., Ohara, H., Masaki, K., et al. (2011). Different enantioselectivity of two types of poly(lactic acid) depolymerases toward poly(l-lactic acid) and poly(d-lactic acid). Polym. Degrad. Stab. 96, 1342-1348. doi: 10.1016/j.polymdegradstab.2011.03.022

Koller, M., and Braunegg, G. (2018). Advanced approaches to produce polyhydroxyalkanoate (PHA) biopolyesters in a sustainable and economic fashion. EuroBiotech. J. 2, 89-103. doi: 10.2478/ebtj-2018-0013

Kourmentza, C., Plácido, J., Venetsaneas, N., Burniol-Figols, A., Varrone, C., Gavala, H. N., et al. (2017). Recent advances and challenges towards sustainable polyhydroxyalkanoate (PHA) production. Bioengineering 4:55. doi: 10.3390/ bioengineering 4020055

Kricheldorf, H. R. (2001). Syntheses and application of polylactides. Chemosphere 43, 49-54. doi: 10.1016/s0045-6535(00)00323-4

Kusaka, S., Iwata, T., and Doi, Y. (1999). Properties and biodegradability of ultra-high-molecular-weight poly[(R)-3-hydroxybutyrate] produced by a recombinant Escherichia coli. Int. J. Biol. Macromol. 25, 87-94. doi: 10.1016/ s0141-8130(99)00019-7

Lasprilla, A. J., Martinez, G. A., Lunelli, B. H., Jardini, A. L., and Filho, R. M. (2012). Poly-lactic acid synthesis for application in biomedical devices-a review. Biotechnol. Adv. 30, 321-328. doi: 10.1016/j.biotechadv.2011.06.019

Lee, G. N., and Na, J. (2013). Future of microbial polyesters. Microb. Cell Fact. 12:54. doi: 10.1186/1475-2859-12-54

Lee, J. Y., Choy, H. E., Lee, J. H., and Kim, G. J. (2015). Generation of minicells from an endotoxin-free Gram-positive strain Corynebacterium glutamicum. J. Microbiol. Biotechnol. 25, 554-558. doi: 10.4014/jmb.1408.08037

Lemoigne, M. (1926). Products of dehydration and of polymerization of $\beta$ hydroxybutyric acid. Bull. Soc. Chem. Biol. 8, 770-782.

Li, G., Zhao, M., Xu, F., Yang, B., Li, X., Meng, X., et al. (2020). Synthesis and biological application of polylactic acid. Molecules 25:5023. doi: 10.3390/ molecules25215023

Li, M., and Wilkins, M. R. (2020). Recent advances in polyhydroxyalkanoate production: feedstocks, strains and process developments. Int. J. Biol. Macromol. 156, 691-703. doi: 10.1016/j.ijbiomac.2020.04.082

López, N. I., Pettinari, M. J., Nikel, P. I., and Méndez, B. S. (2015). Polyhydroxyalkanoates: much more than biodegradable plastics. Adv. Appl. Microbiol. 93, 73-106.

Lutz, J. F., Ouchi, M., Liu, D. R., and Sawamoto, M. (2013). Sequence-controlled polymers. Science 341:1238149.

Madden, L. A., Anderson, A. J., Shah, D. T., and Asrar, J. (1999). Chain termination in polyhydroxyalkanoate synthesis: involvement of exogenous hydroxy-compounds as chain transfer agents. Int. J. Biol. Macromol. 25, 43-53. doi: 10.1016/s0141-8130(99)00014-8

Mamat, U., Wilke, K., Bramhill, D., Schromm, A. B., Lindner, B., Kohl, T. A., et al. (2015). Detoxifying Escherichia coli for endotoxin-free production of recombinant proteins. Microb. Cell Fact. 14:57.

Masood, F., Yasin, T., and Hameed, A. (2015). Polyhydroxyalkanoates - what are the uses? current challenges and perspectives. Crit. Rev. Biotechnol. 35, 514-521. doi: 10.3109/07388551.2014.913548

Masutani, K., and Kimura, Y. (2014). "PLA synthesis. from the monomer to the polymer," in Poly(lactic acid) Science and Technology: Processing, Properties, Additives and Applications, eds A. Jimenez, M. Peltzer, and R. Ruseckaite (London: Royal Society of Chemistry).

Matsumoto, K., and Taguchi, S. (2010). Enzymatic and whole-cell synthesis of lactate-containing polyesters: toward the complete biological production of polylactate. Appl. Microbiol. Biotechnol. 85, 921-932. doi: 10.1007/s00253-0092374-0

Matsumoto, K., and Taguchi, S. (2013a). Biosynthetic polyesters consisting of 2-hydroxyalkanoic acids: current challenges and unresolved questions.
Appl. Microbiol. Biotechnol. 97, 8011-8021. doi: 10.1007/s00253-0135120-6

Matsumoto, K., and Taguchi, S. (2013b). Enzyme and metabolic engineering for the production of novel biopolymers: crossover of biological and chemical processes. Curr. Opin. Biotechnol. 24, 1054-1060. doi: 10.1016/j.copbio.2013. 02.021

Matsumoto, K., Hori, C., Fujii, R., Takaya, M., Ooba, T., Ooi, T., et al. (2018a). Dynamic changes of intracellular monomer levels regulate block sequence of polyhydroxyalkanoates in engineered Escherichia coli. Biomacromolecules 19, 662-671. doi: 10.1021/acs.biomac.7b01768

Matsumoto, K., Ishiyama, A., Sakai, K., Shiba, T., and Taguchi, S. (2011a). Biosynthesis of glycolate-based polyesters containing medium-chain-length 3-hydroxyalkanoates in recombinant Escherichia coli expressing engineered polyhydroxyalkanoate synthase. J. Biotechnol. 156, 214-217. doi: 10.1016/j. jbiotec.2011.07.040

Matsumoto, K., Kobayashi, H., Ikeda, K., Komanoya, T., Fukuoka, A., and Taguchi, S. (2011b). Chemo-microbial conversion of cellulose into polyhydroxybutyrate through ruthenium-catalyzed hydrolysis of cellulose into glucose. Bioresour. Technol. 102, 3564-3567. doi: 10.1016/j.biortech.2010.09.098

Matsumoto, K., Lijima, M., Hori, C., Ooi, T., and Taguchi, S. (2018b). In vitro analysis of D-Lactyl-CoA-polymerizing polyhydroxyalkanoate synthase in polylactate and Poly(lactate- co-3-hydroxybutyrate) syntheses. Biomacromolecules 19, 2889-2895. doi: 10.1021/acs.biomac. $8 \mathrm{~b} 00454$

Matsumoto, K., Terai, S., Ishiyama, A., Sun, J., Kabe, T., Song, Y., et al. (2013). Onepot microbial production, mechanical properties, and enzymatic degradation of isotactic $\mathrm{P}[(\mathrm{R})-2$-hydroxybutyrate] and its copolymer with (R)-lactate. Biomacromolecules 14, 1913-1918. doi: 10.1021/bm400278j

Matsumoto, K., Tobitani, K., Aoki, S., Song, Y., Ooi, T., and Taguchi, S. (2014). Improved production of poly(lactic acid)-like polyester based on metabolite analysis to address the rate-limiting step. AMB Express 4:83.

Mehta, R., Kumar, V., Bhunia, H., and Upadhyay, S. N. (2005). Synthesis of poly(lactic acid): a review. J. Macromol. Sci. Part C Polym. Rev. 45, 325-349.

Meng, D. C., and Chen, G. Q. (2018). Synthetic biology of polyhydroxyalkanoates (PHA). Adv. Biochem. Eng. Biotechnol. 162, 147-174. doi: 10.1007/10_2017_3

Menges, G., Haberstroh, E., Michaeli, W., and Schmachtenberg, E. (2011). Menges Werkstoffkunde Kunststoffe Vol. 5. Germany: Hanser-Verlag.

Miyahara, Y., Hiroe, A., Tsuge, T., and Taguchi, S. (2019). Microbial secretion platform for 3-hydroxybutyrate oligomer and its end-capped forms using chain transfer reaction-mediated polyhydroxyalkanoate Synthases. Biotechnol. J. 14:e1900201. doi: 10.1002/biot.201900201

Moon, S. I., Lee, C. W., Taniguchi, I., Miyamoto, M., and Kimura, Y. (2001a). Melt/solid polycondensation of L-lactic acid: an alternative route to poly(Llactic acid) with high molecular weight. Polymer 42, 5059-5062. doi: 10.1016/ s0032-3861(00)00889-2

Moon, S., Taniguchi, I., Miyamoto, M., Kimura, Y., and Lee, C. (2001b). Synthesis and properties of high-molecular-weight poly(L-lactic acid) by melt/solid polycondensation under different reaction conditions. High. Perform. Polym. 13, 190-197.

Możejko-Ciesielska, J., and Kiewisz, R. (2016). Bacterial polyhydroxyalkanoates: still fabulous? Microbiol. Res. 192, 271-282. doi: 10.1016/j.micres.2016.07.010

Muhammadi, Shabina, Afzal, M., and Hameed, S. (2015). Bacterial polyhydroxyalkanoates-eco-friendly next generation plastic: production, biocompatibility, biodegradation, physical properties and applications. Green Chem. Lett. Rev. 8, 56-77. doi: 10.1080/17518253.2015.1109715

Narancic, T., and O'Connor, K. E. (2019). Plastic waste as a global challenge: are biodegradable plastics the answer to the plastic waste problem? Microbiology 165, 129-137. doi: 10.1099/mic.0.000749

Nduko, J. M., and Taguchi, S. (2019). "Microbial production and properties of LA-based polymers and oligomers from renewable feedstock," in Production of Materials from Sustainable Biomass Resources. Biofuels and Biorefineries, vol 9, eds Z. Fang, R. Smith, and X. F. Tian (Singapore: Springer).

Nduko, J. M., Matsumoto, K., and Taguchi, S. (2012a). "Biological lactate-polymers synthesized by one-pot microbial factory: enzyme and metabolic engineering," in Biobased Monomers Polymers Materials, eds P. B. Smith, and R. A. Gross (New York: American Chemical Society).

Nduko, J. M., Matsumoto, K., and Taguchi, S. (2013b). "Microbial plastic factory: synthesis and properties of the new lactate-based biopolymers," in Green 
Polymer Chemistry: Biocatalysis and Materials II eds H. N. Cheng, P. B. Smith, and R. A. Gross (New York: American Chemical Society).

Nduko, J. M., Matsumoto, K., Ooi, T., and Taguchi, S. (2013a). Effectiveness of xylose utilization for high yield production of lactate-enriched P(lactate-co-3hydroxybutyrate) using a lactate-overproducing strain of Escherichia coli and an evolved lactate-polymerizing enzyme. Metab. Eng. 15, 159-166. doi: 10.1016/j. ymben.2012.11.007

Nduko, J. M., Matsumoto, K., Ooi, T., and Taguchi, S. (2014). Enhanced production of poly(lactate-co-3-hydroxybutyrate) from xylose in engineered Escherichia coli overexpressing a galactitol transporter. Appl. Microbiol. Biotechnol. 98, 2453-2460. doi: 10.1007/s00253-013-5401-0

Nduko, J. M., Sun, J., and Taguchi, S. (2015). "Biosynthesis, properties, and biodegradation of lactate-based polymers," in Green Polymer Chemistry: Biobased Materials and Biocatalysis, eds H. N. Cheng, R. A. Gross, and P. B. Smith (New York: American Chemical Society), 113-131. doi: 10.1021/bk2015-1192.ch008

Nduko, J. M., Suzuki, W., Matsumoto, K., Kobayashi, H., Ooi, T., Fukuoka, A., et al. (2012b). Polyhydroxyalkanoates production from cellulose hydrolysate in Escherichia coli LS5218 with superior resistance to 5-hydroxymethylfurfural. J. Biosci. Bioeng. 113, 70-72. doi: 10.1016/j.jbiosc.2011.08.021

Norhafini, H., Huong, K.-H., and Amirul, A. A. (2019). High PHA density fed-batch cultivation strategies for 4HB-rich $\mathrm{P}(3 \mathrm{HB}-\mathrm{co}-4 \mathrm{HB})$ copolymer production by transformant Cupriavidus malaysiensis USMAA1020. Int. J. Biol. Macromol. 125, 1024-1032. doi: 10.1016/j.ijbiomac.2018.12.121

Plastics Europe (2019). The Facts 2019, An Analysis of European Plastics Production, Demand and Waste Data. Plastics Europe. doi: 10.1016/j.ijbiomac. 2018.12.121

Pollegioni, L., Tonin, F., and Rosini, E. (2015). Lignin-degrading enzymes. FEBS J. 282, 1190-1213. doi: 10.1111/febs.13224

Pretula, J., Slomkowski, S., and Penczek, S. (2016). Polylactides-methods of synthesis and characterization. Adv. Drug Deliv. Rev. 107, 3-16. doi: 10.1016/j. addr.2016.05.002

Raza, Z. A., Abid, S., and Banat, I. M. (2018). Polyhydroxyalkanoates: characteristics, production, recent developments and applications. Int. Biodeterior. Biodegrad. 126, 45-56. doi: 10.1016/j.ibiod.2017.10.001

Ren, C., Chen, T., Zhang, J., Liang, L., and Lin, Z. (2009). An evolved xylose transporter from Zymomonas mobilis enhances sugar transport in Escherichia coli. Microb Cell Fact. 8:66. doi: 10.1186/1475-2859-8-66

Riaz, S., Fatima, N., Rasheed, A., Riaz, M., Anwar, F., and Khatoon, Y. (2018). Metabolic engineered biocatalyst: a solution for PLA based problems. Int. J. Biomater. 2018:1963024.

Sagong, H. Y., Son, H. F., Choi, S. Y., Lee, S. Y., and Kim, K. J. (2018). Structural insights into polyhydroxyalkanoates biosynthesis. Trends Biochem. Sci. 43, 790-805. doi: 10.1016/j.tibs.2018.08.005

Salamanca-Cardona, L., Ashe, C. S., Stipanovic, A. J., and Nomura, C. T. (2014a). Enhanced production of polyhydroxyalkanoates (PHAs) from beechwood xylan by recombinant Escherichia coli. Appl. Microbiol. Biotechnol. 98, 831-842. doi: 10.1007/s00253-013-5398-4

Salamanca-Cardona, L., Scheel, R. A., Bergey, N. S., Stipanovic, A. J., Matsumoto, K., Taguchi, S., et al. (2016). Consolidated bioprocessing of poly(lactate-co3-hydroxybutyrate) from xylan as a sole feedstock by genetically-engineered Escherichia coli. J. Biosci. Bioeng. 122, 406-414. doi: 10.1016/j.jbiosc.2016. 03.009

Salamanca-Cardona, L., Scheel, R. A., Lundgren, B. R., Stipanovic, A. J., Matsumoto, K., Taguchi, S., et al. (2014b). Deletion of the pflA gene in Escherichia coli LS5218 and its effects on the production of polyhydroxyalkanoates using beechwood xylan as a feedstock. Bioengineered 5 , 284-287. doi: 10.4161/bioe.29595

Salamanca-Cardona, L., Scheel, R. A., Mizuno, K., Bergey, N. S., Stipanovic, A. J., Matsumoto, K., et al. (2017). Effect of acetate as a co-feedstock on the production of poly(lactate-co-3-hydroxyalkanoate) by pflA-deficient Escherichia coli RSC10. J. Biosci. Bioeng. 123, 547-554. doi: 10.1016/j.jbiosc. 2016.12.019

Shi, F., Gross, R. A., and Rutherford, D. R. (1996). Microbial polyester synthesis: effects of poly(ethylene glycol) on product composition, repeat unit sequence, and end group structure. Macromolecules 29, 10-17. doi: 10.1021/ma950707j
Shi, M., Cheng, T., Zou, H., Zhang, N., Huang, J., and Xian, M. (2020). The preparation and biomedical application of biopolyesters. Mini Rev. Med. Chem. 20, 331-340. doi: 10.2174/1389557519666191015211156

Shozui, F., Matsumoto, K., Motohashi, R., Sun, J. A., Satoh, T., Kakuchi, T., et al. (2011). Biosynthesis of a lactate (LA)-based polyester with a $96 \mathrm{~mol} \% \mathrm{LA}$ fraction and its application to stereocomplex formation. Polym. Degrad. Stab. 96, 499-504. doi: 10.1016/j.polymdegradstab.2011.01.007

Shozui, F., Matsumoto, K., Motohashi, R., Yamada, M., Taguchi, S. (2010a). Establishment of a metabolic pathway to introduce the 3-hydroxyhexanoate unit into LA-based polyesters via a reverse reaction of $\beta$-oxidation in Escherichia coli LS5218. Polym. Degrad. Stab. 95, 1340-1344. doi: 10.1016/j. polymdegradstab.2010.01.029

Shozui, F., Matsumoto, K., Nakai, T., Yamada, M., and Taguchi, S. (2010b). Biosynthesis of novel terpolymers poly(lactate-co-3-hydroxybutyrate-co-3hydroxyvalerate)s in lactate-overproducing mutant Escherichia coli JW0885 by feeding propionate as a precursor of 3-hydroxyvalerate. Appl. Microbiol. Biotechnol. 85, 949-954. doi: 10.1007/s00253-009-2100-y

Singhvi, M. S., Zinjarde, S. S., and Gokhale, D. V. (2019). Polylactic acid: synthesis and biomedical applications. J. Appl. Microbiol. 127, 1612-1626.

Södergård, A., and Stolt, M. (2002). Properties of lactic acid based polymers and their correlation with composition. Prog. Polym. Sci. 27, 1123-1163. doi: 10. 1016/s0079-6700(02)00012-6

Song, Y., Matsumoto, K., Yamada, M., Gohda, A., Brigham, C. J., and Sinskey, A. J. (2012). Engineered Corynebacterium glutamicum as an endotoxin-free platform strain for lactate-based polyester production. Appl. Microbiol. Biotechnol. 93, 1917-1925. doi: 10.1007/s00253-011-3718-0

Song, Y., Nduko, J. M., Matsumoto, K., and Taguchi, S. (2015). "Microbial factory for the production of polyesters: a new platform of Cornebacterium glutamicum," in Corynebacterium glutamicum: from Systems Biology to Biotechnological Applications ed. A. Burkovski (Poole: Caister Academic Press).

Srubar, W. V., Wright, Z. C., Tsui, A., Michel, A. T., Billington, S. L., and Frank, C. W. (2012). Characterizing the effects of ambient aging on the mechanical and physical properties of two commercially available bacterial thermoplastics. Polym. Degrad. Stab. 97, 1922-1929. doi: 10.1016/j.polymdegradstab.2012. 04.011

Steinbüchel, A., and Valentin, H. E. (1995). Diversity of bacterial polyhydroxyalkanoic acids. FEMS Microbiol. Lett. 128, 219-228. doi: 10.1016/0378-1097(95)00125-o

Subramaniyan, S., and Prema, P. (2002). Biotechnology of microbial xylanases: enzymology, molecular biology, and application. Crit. Rev. Biotechnol. 22, 33-64. doi: 10.1080/07388550290789450

Sun, J., Matsumoto, K., Nduko, J. M., Ooi, T., and Taguchi, S. (2014). Enzymatic characterization of a depolymerase from the isolated bacterium Variovorax sp. C34 that degrades poly (enriched lactate-co-3-hydroxybutyrate). Polym. Degrad. Stab. 110, 44-49. doi: 10.1016/j.polymdegradstab.2014.08.013

Sun, J., Utsunomia, C., Sasaki, S., Matsumoto, K., Yamada, T., Ooi, T., et al. (2016). Microbial production of poly(lactate-co-3-hydroxybutyrate) from hybrid miscanthus-derived sugars. Biosci. Biotechnol. Biochem. 80, 818-820. doi: $10.1080 / 09168451.2015 .1116933$

Surendran, A., Lakshmanan, M., Chee, J. Y., Sulaiman, A. M., Van Thuoc, D., and Sudesh, K. (2020). Can polyhydroxyalkanoates be produced efficiently from waste plant and animal oils? Front. Bioeng. Biotechnol. 8:169.

Suriyamongkol, P., Weselake, R., Narine, S., Moloney, M., and Shah, S. (2007). Biotechnological approaches for the production of polyhydroxyalkanoates in microorganisms and plants-a review. Biotechnol. Adv. 25, 148-175. doi: 10. 1016/j.biotechadv.2006.11.007

Taguchi, S. (2010). Current advances in microbial cell factories for lactatepolymerizing enzymes: toward further creation of new LA-based polyesters. Polym. Degrad. Stab. 95, 1421-1428. doi: 10.1016/j.polymdegradstab.2010.01. 004

Taguchi, S., Ooi, T., Mizuno, K., and Matsusaki, H. (2015). Advances and needs for endotoxin-free production strains. Appl. Microbiol. Biotechnol. 99, 9349-9360. doi: 10.1007/s00253-015-6947-9

Taguchi, S., Yamada, M., Matsumoto, K., Tajima, K., Satoh, Y., Munekata, M., et al. (2008). A microbial factory for lactate-based polyesters using a 
lactate-polymerizing enzyme. Proc. Natl. Acad. Sci. USA 105, 17323-17327. doi: 10.1073/pnas.0805653105

Tajima, K., Satoh, Y., Satoh, T., Itoh, R., Han, X. R., Taguchi, S., et al. (2009). Chemo-enzymatic synthesis of poly(lactate-co-(3-hydroxybutyrate)) by a lactate-polymerizing enzyme. Macromolecules 42, 1985-1989. doi: 10.1021/ ma802579g

Takisawa, K., Ooi, T., Matsumoto, K., Kadoya, R., and Taguchi, S. (2017). Xylosebased hydrolysate from Eucalyptus extract as feedstock for poly(lactate-co-3hydroxybutyrate) production in engineered Escherichia coli. Proc. Biochem. 54, 102-105. doi: 10.1016/j.procbio.2016.12.019

Takkellapati, S., Li, T., and Gonzalez, M. A. (2018). An overview of biorefinery derived platform chemicals from a cellulose and hemicellulose biorefinery. Clean Technol. Environ. Policy 20, 1615-1630. doi: 10.1007/s10098-018-1568-5

Tarrahi, R., Fathi, Z., Seydibeyoğlu, M. Ö, Doustkhah, E., and Khataee, A. (2020). Polyhydroxyalkanoates (PHA): from production to nanoarchitecture. Int. J. Biol. Macromol. 146, 596-619. doi: 10.1016/j.ijbiomac.2019.12.181

Thomson, N. M., Hiroe, A., Tsuge, T., Summers, D. K., and Sivaniah, E. (2014). Efficient molecular weight control of bacterially synthesized polyesters by alcohol supplementation. J. Chem. Technol. Biotechnol. 89, 1110-1114. doi: $10.1002 /$ jctb. 4198

Tomizawa, S., Saito, Y., Hyakutake, M., Nakamura, Y., Abe, H., and Tsuge, T. (2010). Chain transfer reaction catalyzed by various polyhydroxyalkanoate synthases with poly(ethylene glycol) as an exogenous chain transfer agent. Appl. Microbiol. Biotechnol. 87, 1427-1435. doi: 10.1007/s00253-0102601-8

Tran, T. T., and Charles, T. C. (2020). Lactic acid containing polymers produced in engineered Sinorhizobium meliloti and Pseudomonas putida. PLoS One 15:e0218302. doi: 10.1371/journal.pone.0218302

Tyler, B., Gullotti, D., Mangraviti, A., Utsuki, T., and Brem, H. (2016). Polylactic acid (PLA) controlled delivery carriers for biomedical applications. Adv. Drug Deliv. Rev 107, 163-175. doi: 10.1016/j.addr.2016.06.018

Utrilla, J., Licona-Cassani, C., Marcellin, E., Gosset, G., Nielsen, L. K., and Martinez, A. (2012). Engineering and adaptive evolution of Escherichia coli for D-lactate fermentation reveals GatC as a xylose transporter. Metab. Eng. 14, 469-476. doi: 10.1016/j.ymben.2012.07.007

Utsunomia, C., Hori, C., Matsumoto, K., and Taguchi, S. (2017a). Investigation of the Escherichia coli membrane transporters involved in the secretion of D-lactate-based oligomers by loss-of-function screening. J. Biosci. Bioeng. 124, 635-640. doi: 10.1016/j.jbiosc.2017.06.018

Utsunomia, C., Matsumoto, K., and Taguchi, S. (2017c). Microbial secretion of D-lactate-based oligomers. ACS Sus. Chem. Eng. 5, 2360-2367. doi: 10.1021/ acssuschemeng.6b02679

Utsunomia, C., Matsumoto, K., Date, S., Hori, C., and Taguchi, S. (2017b). Microbial secretion of lactate-enriched oligomers for efficient conversion into lactide: a biological shortcut to polylactide. J. Biosci. Bioeng. 124, 204-208. doi: 10.1016/j.jbiosc.2017.03.002

Van Wouwe, P., Dusselier, M., Vanleeuw, E., and Sels, B. (2016). Lactide synthesis and chirality control for polylactic acid production. ChemSusChem. 9, 907-921. doi: 10.1002/cssc. 201501695

Verma, R., Vinoda, K. S., Papireddy, M., and Gowda, A. N. S. (2016). Toxic pollutants from plastic waste- a review. Procedia Environ. Sci. 35, 701-708. doi: 10.1016/j.proenv.2016.07.069

Vijayendra, S. V., and Shamala, T. R. (2014). Film forming microbial biopolymers for commercial applications-a review. Crit. Rev. Biotechnol. 34, 338Ü357. doi: 10.3109/07388551.2013.798254
Vink, E. T. H., and Davies, S. (2015). Life cycle inventory and impact assessment data for 2014 IngeoTM polylactide production. Ind. Biotechnol. 11, 167-180. doi: 10.1089/ind.2015.0003

Volova, T. G., Prudnikova, S. V., Vinogradova, O. N., Syrvacheva, D. A., and Shishatskaya, E. I. (2017). Microbial degradation of polyhydroxyalkanoates with different chemical compositions and their biodegradability. Microbial. Ecol. 73, 353-367. doi: 10.1007/s00248-016-0852-3

Wang, S., Chen, W., Xiang, H., Yang, J., Zhou, Z., and Zhu, M. (2016). Modification and potential application of short-chain-length polyhydroxyalkanoate (SCLPHA). Polymers 8:273. doi: 10.3390/polym8080273

Wolf, F. F., Friedemann, N., and Frey, H. (2009). Poly(lactide)-block-Poly(HEMA) block copolymers: an orthogonal one-pot combination of ROP and ATRP, using a bifunctional initiator. Macromolecules 42, 5622-5628. doi: 10.1021/ ma900894d

Worch, J. C., Prydderch, H., Jimaja, S., Bexis, B., Becker, M. L., and Dove, A. P. (2019). Stereochemical enhancement of polymer properties. Nat. Rev. Chem. 3, 514-535. doi: 10.1038/s41570-019-0117-z

Xu, J., Li, C., Dai, L., Xu, C., Zhong, Y., Yu, F., et al. (2020). Biomass fractionation and lignin fractionation towards lignin valorization. ChemSusChem 13, 42844295. doi: $10.1002 /$ cssc. 202001491

Yamada, M., Matsumoto, K., Nakai, T., and Taguchi, S. (2009). Microbial production of lactate-enriched poly[(R)-lactate-co-(R)-3-hydroxybutyrate] with novel thermal properties. Biomacromolecules 10, 677-681. doi: 10.1021/ bm8013846

Yamada, M., Matsumoto, K., Shimizu, K., Uramoto, S., Nakai, T., Shozui, F., et al. (2010). Adjustable mutations in lactate (LA)-polymerizing enzyme for the microbial production of LA-based polyesters with tailor-made monomer composition. Biomacromolecules 11, 815-819. doi: 10.1021/bm90 $1437 \mathrm{z}$

Yamada, M., Matsumoto, K., Uramoto, S., Motohashi, R., Abe, H., and Taguchi, S. (2011). Lactate fraction dependent mechanical properties of semitransparent poly(lactate-co-3-hydroxybutyrate)s produced by control of lactyl-CoA monomer fluxes in recombinant Escherichia coli. J. Biotechnol. 154, 255-260. doi: 10.1016/j.jbiotec.2011.05.011

Yang, J. E., Choi, S. Y., Shin, J. H., Park, S. J., and Lee, S. Y. (2013). Microbial production of lactate-containing polyesters. Microbial. Biotechnol. 6, 621-636. doi: 10.1111/1751-7915.12066

Zhang, X., Lin, Y., Wu, Q., Wang, Y., and Chen, G. Q. (2020). Synthetic biology and genome-editing tools for improving PHA metabolic engineering. Trends Biotechnol. 38, 689-700. doi: 10.1016/j.tibtech.2019.10.006

Zhou, L., Zuo, Z. R., Chen, X. Z., Niu, D. D., Tian, K. M., Prior, B. A., et al. (2011). Evaluation of genetic manipulation strategies on D-lactate production by Escherichia coli. Curr. Microbiol. 62, 981-989. doi: 10.1007/s00284-0109817-9

Conflict of Interest: The authors declare that the research was conducted in the absence of any commercial or financial relationships that could be construed as a potential conflict of interest.

Copyright (c) 2021 Nduko and Taguchi. This is an open-access article distributed under the terms of the Creative Commons Attribution License (CC BY). The use, distribution or reproduction in other forums is permitted, provided the original author(s) and the copyright owner(s) are credited and that the original publication in this journal is cited, in accordance with accepted academic practice. No use, distribution or reproduction is permitted which does not comply with these terms. 